\title{
Bioengineering Embryonic Stem Cell Microenvironments for the Study of Breast Cancer
}

\author{
Nurazhani Abdul Raof, Bridget M. Mooney and Yubing Xie * \\ College of Nanoscale Science \& Engineering, University at Albany (SUNY), Albany, NY 12202, \\ USA; E-Mails: nabdulraof@albany.edu (N.A.R.); bm0675@albany.edu (B.M.M.) \\ * Author to whom correspondence should be addressed; E-Mail: yxie@albany.edu; \\ Tel.: +1-518-956-7381; Fax: +1-518-437-8687.
}

Received: 21 September 2011; in revised form: 27 October 2011 / Accepted: 31 October 2011 / Published: 8 November 2011

\begin{abstract}
Breast cancer is the most prevalent disease amongst women worldwide and metastasis is the main cause of death due to breast cancer. Metastatic breast cancer cells and embryonic stem (ES) cells display similar characteristics. However, unlike metastatic breast cancer cells, ES cells are nonmalignant. Furthermore, embryonic microenvironments have the potential to convert metastatic breast cancer cells into a less invasive phenotype. The creation of in vitro embryonic microenvironments will enable better understanding of ES cell-breast cancer cell interactions, help elucidate tumorigenesis, and lead to the restriction of breast cancer metastasis. In this article, we will present the characteristics of breast cancer cells and ES cells as well as their microenvironments, importance of embryonic microenvironments in inhibiting tumorigenesis, convergence of tumorigenic and embryonic signaling pathways, and state of the art in bioengineering embryonic microenvironments for breast cancer research. Additionally, the potential application of bioengineered embryonic microenvironments for the prevention and treatment of invasive breast cancer will be discussed.
\end{abstract}

Keywords: stem cell; microenvironment; hydrogel; three-dimensional culture; breast cancer; metastasis; co-culture 


\section{Introduction}

According to the International Agency for Research on Cancer, breast cancer is the most frequently diagnosed malignant disease and leading cause of cancer deaths among women worldwide. In 2011, it is estimated that 230,480 women in the United States will be diagnosed with invasive breast cancer and 57,650 with noninvasive breast cancer, from which 39,520 women will die [1]. Despite the fact that the death rate of breast cancer is expected to decrease due to better awareness, early detection and improved treatment, it is anticipated that breast cancer will remain the second leading cause of death after heart disease in the United States.

Breast cancer occurs when cells in the lining of the milk duct or the lobules that provide milk to the duct undergo a series of mutations. These mutations may take several years to develop. The cause of these cellular mutations is still under investigation but may be attributed to several factors including aging, family history, carcinogens, poor diet, smoking and excessive drinking. Breast cancer cells proliferate uncontrollably and may induce metastasis, which is the main cause of death associated with breast cancer [2,3]. Metastasis is the complex process in which cancer cells spread out to other parts of the body through the bloodstream or the lymphatic system [4]. Tumor microenvironments play an important role in the regulation of metastasis [5-8]. The communication between cancer cells and their microenvironments triggers cancer cells to break away from the original tumor and invade other areas of the body [9-12]. Cell migration and invasion play a pivotal role in the onset of metastasis. Current treatments focused on eradicating metastatic cancer cells include systemic therapy (e.g., chemotherapy, hormonal therapy, biological therapy) and local therapy (e.g., surgery, mastectomy, lumpectomy). While advances in science and technology have aided in providing improved treatments to reduce the number of deaths caused by breast cancer, it remains a huge challenge to fully understand the mechanisms of cell migration and invasion, and to completely eliminate cancer cells to prevent disease recurrence and metastasis. The engineering of unique tumor microenvironments in vitro which can manipulate the proliferation and migration of metastatic breast cancer cells may permit enhanced study of cancer metastasis. Consequently, this could provide greater insight into the decision-making processes regarding the growth, migration, and invasion of cancer cells and its subsequent prevention.

With the advancement of embryonic stem (ES) cell technology, the use of bioengineered ES cell microenvironments provides an ideal platform to study and understand the inhibition along with the metastatic potential of invasive breast cancer cells in vitro. Firstly, the undifferentiated ES cell microenvironment represents a unique microenvironment to counteract tumorigenesis and metastasis. Prior studies indicate that cancer cells generally interact with a microenvironment that facilitates plasticity, tumorigenicity and metastasis [5,9,13-15], while ES cells sustain a microenvironment regulating self-renewal and differentiation $[16,17]$. The embryonic microenvironment has the potential to reverse the malignancy state of tumors as it might consist of environmental factors that have the ability to reprogram cancer cells into a less invasive phenotype [18-25]. Furthermore, research has indicated that the undifferentiated ES cell microenvironment reduces cancer cell growth, as opposed to, the differentiated microenvironment which increases growth [26]. Secondly, since breast cancer cells are believed to originate from mutations caused by rapidly dividing stem cells, attempts to restore the mutated tumor microenvironment with a bioengineered embryonic microenvironment may overturn cancer cell progression. Thirdly, the creation of ES cell microenvironments may help identify 
anti-tumor and/or anti-metastasis factors through the study of interactions of ES cells and metastatic breast cancer cells. In addition to discovering the ability of the ES cell microenvironment to halt cancer cell growth and migration, the co-culture of ES cells and breast cancer cells would also offer the recreation of in vitro breast cancer models for mechanism studies and drug screening.

In this review, we will summarize findings regarding the utilization of the embryonic microenvironment in vivo and in vitro to understand and inhibit cancer metastasis. A brief discussion of breast cancer cell and embryonic stem cell characteristics will be included. Lastly, we will discuss the recent discovery within our own laboratory that bioengineered 3D embryonic microenvironments inhibit the proliferation and migration of metastatic breast cancer cells. Together, the study of ES cell-cancer cell interactions in a bioengineered system will provide valuable insight into the fundamental understanding of tumor progression and therapeutic development for metastatic diseases.

\section{Characteristics of Breast Cancer Cells and Tumor Microenvironments}

\subsection{Uncontrolled Tumor Growth}

Excessive cancer cell proliferation is due to the overexpression of proteins produced by oncogenes, which are created via the mutation of normal proto-oncogenes and tumor suppressor genes. Mutated cells do not respond to typical cell cycle regulation mechanisms such as programmable cell death, known as apoptosis, leading to the overgrowth of damaged cells. For instance, proto-oncogenes as well as cell surface receptors, erb-B2 and epidermal growth factor receptor (EGFR) are normally activated after the binding of the EGF ligand to induce normal cell proliferation. The binding subsequently induces erb-B2 and EGFR endocytosis and regulates the normal intracellular signaling cascade. In contrast, the erb-B2 and EGFR oncogenes, which are categorized under the receptor tyrosine kinases family, send signals to promote cancer cell division without having to bind to any growth factors resulting in dramatic, uncontrolled growth of tumor cells. In addition, the overexpression of EGFR and erb-B2 oncogenes stimulates invasiveness of breast cancer cells [27].

Other important mutant proto-oncogenes that are responsible for breast cancer cell proliferation and differentiation include cyclins, cyclin dependent kinases (CDK), the tyrosine kinase family of growth factor receptors, and the c-myc oncogene [28]. The mutated/transformed tumor suppressor genes that accelerate the breast cancer cell growth include $\mathrm{p} 53$, retinoblastoma $(\mathrm{Rb})$ gene, BRCA1 and BRCA2, PTEN, ATM, Brush-1, Maspin and nm231 [29]. These previously mentioned oncogenes are just a few examples of impaired genes in breast cancer as there are over thousands of reported deviations within the genome [30-32].

\subsection{Metastasis}

In order for metastasis to occur, breast cancer cells must first undergo several critical cascades influenced by genetic or epigenetic modifications. Initially, breast cancer cells proliferate rapidly enhancing their aggressiveness due to the presence of oncogenes. The extracellular matrix (ECM) surrounding breast cancer cells, is subsequently degraded by matrix metalloproteases (MMPs) allowing cells to migrate and invade the stroma. MMPs are a family of proteinases that regulate cell signaling to promote growth, inflammation, and/or angiogenesis [33]. In addition to MMPs, the 
delocalization of cancer cells from the primary tumor is also caused by the decrement in the expression of cell adhesion proteins, for example, CD44 [34], E-cadherins [35], integrin [36], and vimentin [35]. During this phase, cancer cells in the primary tumor are transitioning in what is referred to as epithelial-mesenchymal transition (EMT), which is essentially a program that induces cells to be highly mobilized in order to migrate away [37,38]. Breast cancer cell migration is guided by chemokines through the paracrine loop, such as CCL18 [39], CCR4 [40], CCL25 [41], CXCL14 and CXCL15 [42]. Additionally, invasive breast cancer cells, MDA-MB-231, undergo metastasis in vivo based on the communication between their secreted factors, colony stimulating factor-1 (CSF-1) and EGF, which are growth factors released by surrounding macrophages [43]. Transcription factors involved during the EMT state of breast cancer include Snail, Slug, Twist, Six1, Lbx1, and ZEB [44]. The known signaling pathways that influence the behavior of these transcription factors during EMT are TGF- $\beta$, Wnt/ $\beta$-catenin, and Msx2/Cripto pathways [45]. Moreover, tumor necrosis factor-alpha $(\mathrm{TNF}-\alpha)$ is involved in the promotion of metastasis. TNF- $\alpha$ is a transmembrane protein that stimulates tumor proliferation and survival via NF- $\kappa \mathrm{B}-\mathrm{PKC} \alpha$ - and AP-1-dependent signaling pathways [46].

The morphological processes of a cancer cell during the EMT phase are termed lamellipodia, filopodia and invadopodia, and are governed by a very active actin-cytoskeletal component and a high concentration of proteases [47,48]. Briefly, lamellipodia are wide protrusions located at the edge of cells during motility, while filopodia are long and thin actin filaments protruding several micrometers ahead beyond the lamellipodia coverage. Invadopodia are structures possessed by cells that are highly enriched in actin filaments and are responsible for degrading the ECM to drive cancer cell invasion. One critical actin-binding protein that facilitates normal cellular migration is Profilin1. It has been reported that the down-regulation of this protein promotes motility in breast cancer cells (MD-MB-231) through the increased amount of lamellipodia [49,50]. Another well-known actin skeletal protein that drives metastasis is Mena. Mena is upregulated and highly expressed in invasive breast cancer cells [51]. Regarding breast cancer motility during metastasis, two types of cancer cell migration exist and are termed amoeboid migration and collective cell migration [52]. Amoeboid migration is defined as the movement of cells that have reduced focal adhesions and maintained high flexibility. Collective cell migration refers to the cell movement while in contact with neighboring cells. Following the migration, highly motile breast cancer cells will move directionally towards blood vessels and enter the blood or lymphatic vasculature via intravasation [53]. As a result the invasive breast cancer cells migrate out of the primary tumor via blood vessels and reach a secondary organ in the body via extravasation, creating a new metastatic site.

\subsection{Tumor Microenvironment}

Breast cancer cell growth and behavior that promotes metastasis is mainly influenced by the complex and highly structured microenvironment [15,54-59]. The tumor microenvironment consists of soluble factors, ECM and neighboring cells $[8,60]$. Soluble factors include encircling cytokines and growth factors that have the potential to guide cells toward a malignant state. MMPs exemplify soluble factors that modulate the tumor microenvironment [33]. There are several types of MMPs that work synergistically to induce breast cancer metastasis [61]. MMPs function by cleaving cell surface receptors, which in turn, detaches the bound ECM. Consequently, this process leads to the degradation 
of the ECM that permits breast cancer cells to migrate and intravasate. Prior studies indicate that MMP-1, -2, -8, -9 -10, -11, -12, -13, -15, -19, -23, -24, -27 and -28 promote breast cancer development and tumor progression [62]. In particular, MMP-1, -9 , and -13 are strongly correlated with the incidence of breast cancer metastasis and are potential markers for poor prognosis of invasive breast cancer [63-66]. The activity of MMPs can be inhibited by endogenous tissue inhibitor of metalloproteinases (TIMPs), including TIMP-1, TIMP-2, TIMP-3, and TIMP-4 [67]. Among these inhibitors, TIMP-1 inhibits MMP-1, -3 , and -9 more effectively than TIMP-2 [68-70], while all types of TIMPs are able to inhibit active MMP-13 [71,72]. Another critical soluble factor that is highly expressed in the tumor microenvironment is EGF [73]. EGF stimulates the proliferation of breast cancer cells by binding to EGFR which is one of the oncogenes of breast cancer. EGF also displays chemotactic properties in facilitating cell migration towards metastasis [74]. Two additional examples of growth factors associated with the development of metastatic breast cancer include fibroblast growth factors (FGF) [75] and transforming growth factor- $\beta$ (TGF- $\beta$ ) [76].

Within the tumor microenvironment, the ECM constitutes the basement membrane and the interstitial matrix, providing a cushion for cells to grow. The mechanical properties of cancer cells, dictated by external exertion from the surrounding microenvironment, impact the degree of invasiveness as well [77]. The ECM is defined as connective tissues comprised of fibrous proteins and polysaccharides. The bidirectional communication and interaction between cancer cells and the ECM contributes to the progression of metastasis. Major components of the ECM in the basement membrane include collagen, elastin, laminin and fibronectin. The interstitial matrix consists of polysaccharides such as proteoglycans and hyaluronic acid. Breast cancer cells are attached to the ECM and other cells via transmembrane glycoproteins such as integrin and E-cadherin. The loss of these proteins is one of the hallmarks of cancer metastasis [78]. Reportedly, the reduced expression of these proteins is associated with other contributing factors in the tumor microenvironment such as TGF- $\beta$ [79] and MMPs [80].

Another critical factor in the tumor microenvironment is neighboring cells. Fibroblasts, myoepithelial cells, adipocytes, endothelial cells, and leukocytes are examples of cells that surround breast cancer cells. In addition to providing scaffolds for cancer cells to grow, these cells secrete signals, cytokines, and growth factors that may increase the malignancy of cancer cells [81]. The term tumor microenvironment of metastasis (TMEM) coined by Robinson et al. includes three critical cells in the tumor microenvironment: an invasive carcinoma cell, a macrophage, and an endothelial cell. The researchers discovered that the density of TMEM was higher in metastatic patients as compared to primary breast cancer patients [82]. A study by Yizraeli et al. reported that following the direct application of an electric field to induce apoptosis in breast cancer cells, the apoptotic event was delayed when these cells were co-cultured with fibroblasts as opposed to breast cancer cells alone [83]. This result illustrates the importance of neighboring cells, fibroblasts in this case, in governing tumor malignancy. Furthermore, considering the fact that surrounding cells play a significant role in directing metastasis, in vitro co-culture of breast cancer cells with other cells may increase understanding of tumorigenesis. For instance, MCF-7 breast cancer cell proliferation was inhibited when co-cultured with preadipocytes [84]. Additionally, breast cancer cells cultured three dimensionally in the presence of normal breast fibroblasts displayed reversion of tumor phenotype [85] and formation of ductal structures [86]. Several studies have also revealed the enhancement of tumorigenicity of breast cancer 
cells when they were co-cultured with adipocytes [87], benign mammary epithelial cells [88], bone marrow stem cells [89] and endothelial cells [90]. Reconstructing a human breast cancer model is indeed crucial and theoretically more physiologically relevant with respect to attaining proper understanding of cell-cell interaction related to metastasis.

\subsection{Reprogramming Breast Cancer Cells}

It is possible to halt breast cancer cell progression under certain conditions. Firstly, it may be accomplished through the arrest of cell proliferative capacity, termed cellular senescence [91], which involves the shortening of telomeres [92] or p53 activation [93]. Secondly, blocking of oncogenes contained in breast cancer cells and their microenvironment may facilitate the overturn of cell proliferation and migration. One great example is the treatment of Trastuzumab, a humanized anti-HER2/neu antibody, to inhibit erb-B2 tyrosine kinase receptor (TKR) oncogenic activity [94]. Another possible blocking mechanism is the arrest of MMP activity. Since MMPs play a critical role in tumor invasion and metastasis through the degradation of the ECM, impeding the enzyme may reduce tumorigenesis. The major inhibitors of MMPs include TIMP1 and TIMP2 [95]. Furthermore, blocking the growth factor receptors involved in promoting breast cancer aggressiveness may also contribute to the anti-proliferative capability of cells [96]. The obstruction of the receptor involved in invadopodia formation, platelet derived growth factor receptor (PDGFR), through its transcription factor, Twist1, prevents breast cancer metastasis [97]. Additionally, targeting cell adhesion proteins such as integrin by creating its antagonist is a promising anti-cancer therapeutic strategy [98]. The blocking of certain oncogenes and signaling pathways may induce apoptosis in breast cancer cells as well [99], leading to potential alternatives in breast cancer therapy.

Considering the fact that the tumor microenvironment has emerged as a significant and vital component that drives metastasis, targeting the breast cancer cell microenvironment may be one of the potential solutions in reprogramming breast cancer invasiveness [100]. In particular, this review focuses on utilizing the embryonic microenvironment to replace the tumor microenvironment in order to reprogram cancer cells into a less invasive phenotype, thereby, reducing the instances of metastasis.

\section{Characteristics of Embryonic Stem Cells and Microenvironments}

\subsection{Self-Renewal and Pluripotency of Embryonic Stem Cells}

ES cells originate from the inner cell mass of the blastocyst which forms a few days after the fertilization process. ES cells are taken from the blastocyst and cultured in the lab in vitro. ES cells have the capability to self-renew indefinitely making them a significant source of cell regeneration. Additionally, these cells are unique in that they are pluripotent meaning they have the potential to differentiate into all cell types found within the three germ layers - the ectoderm, mesoderm and endoderm. These remarkable and unique properties make ES cells valuable in areas such as regenerative medicine, drug discovery, and diagnostics.

The indefinite self-renewal of ES cells is controlled by several proteins and genes. Transcription factors Oct4, Nanog and Sox2 play a major role in guiding ES cells to proliferate [101]. The downregulation of these genes causes ES cells to undergo differentiation [102]. In this article, we will 
focus on the microenvironment of undifferentiated ES cells as they restrict tumor cell growth and metastasis, as opposed to differentiated ES cells which promote the growth of tumor cells [26]. Interestingly, Oct4, which is a potent canonical marker for ES cell pluripotency, is downregulated during the EMT phase of breast cancer cells [103]. This particular finding may also indicate that the loss of Oct4 expression in differentiated ES cells creates a microenvironment favorable to tumorigenesis. In the presence of leukemia inhibitory factor (LIF), mouse ES cells hypothetically release certain chemokines/cytokines and growth factors, including interleukin (IL)-1 $\alpha$, IL-10, IL-11, macrophage-colony stimulating factor (M-CSF), oncostatin M, stem cell factor (SCF), VEGF, CXCL1, 2, 6, and 10, CCL2, 4, 7, and 22, CD 40, MMP-9, and TIMP-1 (listed in Table 1) [104]. These cytokines and growth factors provide signals for ES cells to remain alive and retain the capacity for self-renewal and pluripotency. Additionally, the effects of these soluble factors on breast cancer cells are listed in table 1. Although comparable factors are present, breast cancer cells contain mutated genes that lead to under- or overexpression of these chemokines/cytokines and growth factors. Therefore, different levels are present in the tumor microenvironment compared to the ES cell microenvironment. As shown in Table 1, breast cancer cells secrete much higher level of M-CSF, OSM, MIP-2/CXCL-2, MMP-9 and TIMP-1 than ES cells, which are factors correlated with tumor metastasis.

Table 1. Comparable soluble factors secreted by murine embryonic stem (ES) cells and breast cancer cells and their effects on the latter cells.

\begin{tabular}{|c|c|c|c|c|}
\hline Name & $\begin{array}{l}\text { Molecular } \\
\text { Weight } \\
\text { (kDa) }\end{array}$ & $\begin{array}{c}\text { C }(\mathbf{p g} / \mathrm{mL}) \\
\text { Secreted by } \\
\text { ES Cells [104] }\end{array}$ & $\begin{array}{c}\mathrm{C}(\mathrm{pg} / \mathrm{mL}) \\
\text { Released by Breast } \\
\text { Cancer Cells }\end{array}$ & Effects on Breast Cancer Cells \\
\hline CYTOKINES & $20-45$ & & & \\
\hline IL-10 & 20 & +++ & ++ & $\begin{array}{l}\text { Expressed in tumor samples [105] } \\
\text { and associated with reduced } \\
\text { disease-free survival [106] }\end{array}$ \\
\hline IL-11 & 23 & ++ & +++ & $\begin{array}{l}\text { Produced by breast cancer } \\
\text { cells [107] and linked to poor } \\
\text { survival [108] }\end{array}$ \\
\hline IL-1 $\alpha$ & 33 & ++ & +++ & $\begin{array}{l}\text { Expressed in poorly differentiated, } \\
\text { ER } \alpha \text {-negative tumors [109] }\end{array}$ \\
\hline $\mathrm{M}-\mathrm{CSF}$ & 18.5 & +++ & ++++ & $\begin{array}{l}\text { CSF-1/CSF-1R autocrine signaling } \\
\text { contributed to the invasion } \\
\text { phenotype of breast cancer [42] }\end{array}$ \\
\hline $\begin{array}{l}\text { OSM } \\
\text { (Oncostatin M) }\end{array}$ & 28 & ++ & ++++++ & $\begin{array}{l}0.1-100 \mathrm{ng} / \mathrm{mL} \text { OSM: inhibited } \\
\text { proliferation/changed cell } \\
\text { morphology [110,111]; } \\
20-50 \mathrm{ng} / \mathrm{mL} \text { OSM: increased } \\
\text { invasive potential [112] }\end{array}$ \\
\hline $\begin{array}{l}\text { SCF } \\
\text { (Stem Cell } \\
\text { Factor) }\end{array}$ & 45 & ++ & - & $\begin{array}{l}\text { High expression of SCF and SCF-R } \\
\text { in normal mammary samples and } \\
\text { low in invasive tumors [113]; } \\
\text { enhanced activation of the MAPK } \\
\text { and PI3K pathways [114] }\end{array}$ \\
\hline
\end{tabular}


Table 1. Cont.

\begin{tabular}{|c|c|c|c|c|}
\hline Name & $\begin{array}{c}\text { Molecular } \\
\text { Weight } \\
\text { (kDa) }\end{array}$ & $\begin{array}{c}C(p g / m L) \\
\text { Secreted by } \\
\text { ES Cells [104] }\end{array}$ & $\begin{array}{c}\mathrm{C}(\mathrm{pg} / \mathrm{mL}) \\
\text { Released by Breast } \\
\text { Cancer Cells }\end{array}$ & Effects on Breast Cancer Cells \\
\hline CYTOKINES & $20-45$ & & & \\
\hline VEGF & 42 & +++ & +++ & Angiogenic effect [115] \\
\hline CHEMOKINES & $<13$ & & & \\
\hline GCP-2/CXCL6 & 8 & ++ & - & $\begin{array}{l}\text { Upregulated in breast cancer } \\
\text { cells [116] }\end{array}$ \\
\hline IP-10/CXCL10 & 10 & +++ & +++ & $\begin{array}{l}\text { Promote metastasis in a murine } \\
\text { model [117] }\end{array}$ \\
\hline${ }_{1}^{\mathrm{KC} / \mathrm{GRO} \alpha / \mathrm{CXCL}}$ & 11.3 & +++ & - & Angiogenic effect [118] \\
\hline MCP-1/CCL2 & $11-13$ & +++ & +++ & $\begin{array}{l}\text { Highly expressed in breast } \\
\text { tumor [119] }\end{array}$ \\
\hline MCP-3/CCL7 & 11 & ++ & - & $\begin{array}{l}\text { Overexpressed in breast carcinoma } \\
\text { patients }[120]\end{array}$ \\
\hline MDC/CCL22 & 8.1 & ++ & - & $\begin{array}{l}\text { Involved in breast cancer lung } \\
\text { metastasis [121] }\end{array}$ \\
\hline MIP-1 $\beta / C C L 4$ & 7.8 & ++ & +++ & $\begin{array}{l}\text { Downregulated in breast carcinoma } \\
\text { patients }[120]\end{array}$ \\
\hline MIP-2/CXCL2 & 6 & + & +++ & $\begin{array}{l}\text { Highly expressed in bone metastatic } \\
\text { breast cancer [122] }\end{array}$ \\
\hline OTHERS & $>29$ & & & \\
\hline $\mathrm{CD} 40$ & 43 & ++ & - & $\begin{array}{l}\text { Anti-tumor activity in breast cancer } \\
\text { cells [123] }\end{array}$ \\
\hline MMP-9 & 90 & ++++ & +++++ & $\begin{array}{l}\text { Overexpressed in breast cancer } \\
\text { cells [64] }\end{array}$ \\
\hline TIMP-1 & 29 & +++++ & ++++++ & $\begin{array}{l}\text { Inhibits breast cancer cell } \\
\text { apoptosis [124] }\end{array}$ \\
\hline
\end{tabular}

\subsection{Embryonic Microenvironments}

The embryonic microenvironment plays a crucial role in determining the cellular fate of embryonic stem cells: whether to direct cells to self-renew, proliferate, differentiate, remain inactive or experience death. The general components of the embryonic microenvironment also include soluble factors, ECM and neighboring cells. The ECM regulates ES cell signaling in a spatially-patterned fashion by providing structural support to cells, integrating complex cellular signals, and controlling the distribution and activation of growth factors. To mimic the ES cell microenvironment, mouse [125] and human embryonic fibroblasts [126] are initially incorporated as a feeder layer to maintain ES cells in an undifferentiated state. Matrigel [127] and ECM proteins [128] are employed to support the maintenance of ES cell pluripotency in feeder layer-free cultures. Soluble factors for self-renewal of ES cells include LIF for mouse ES cells [129] and basic fibroblast growth factor (bFGF) for human ES cells [130]. Additionally, insulin growth factor-receptor (IGF-R), erb-B2 receptor signaling, and activin-A are required to maintain human ES cell pluripotency [131]. 


\subsection{Bioengineering Embryonic Stem Cell Microenvironments}

The microenvironments of ES cells play a fundamental role in providing cells with appropriate signaling to induce cell proliferation, differentiation or death. The bioengineering of ES cell microenvironments in vitro may permit the emulation of the heterogeneous and highly complex nature of ES cells, enabling a clearer understanding of stem cell fate decision. In order to recapitulate the native stem cell niche, researchers have exploited several bioengineering methods. For example, to replicate the ECM, various types of scaffolds composed of naturally and synthetically derived polymers, or both, have been engineered. Naturally derived polymers include alginate, gelatin, Matrigel and chitosan. Poly(L-lactic acid) (PLLA), poly(ethylene glycol) (PEG) and poly(e-caprolactone) (PCL) are examples of synthetic polymers. Researchers have demonstrated that human ES cell pluripotency is maintained when the ES cells are cultured in a 3D hyaluronic acid [132], alginate [133,134], or chitosan scaffold [135]. Specifically, our lab has reported that mouse ES cells encapsulated inside aqueous alginate hydrogel microstrands prefer differentiation towards either a mesoderm or endoderm lineage [136]. A study by Peng S. et al. revealed that mouse ES cells cultured on gelatin induces cell differentiation into trophectoderm [137]. Furthermore, the application of synthetic polymers within the field of nanotechnology for stem cell culture is mainly the fabrication of nanofibers. For instance, human ES cells cultured on nanofibrous scaffolds exhibit a greater affinity for hepatocyte [138], neuronal [139] and osteogenic differentiation [140,141]. Additionally, mouse ES cells seeded on PCL nanofibers undergo directed differentiation into adipocyte [142] and neural lineages [143]. It is also worth noting that the main purpose of these synthetic nanofibrous scaffolds is to guide stem cell differentiation. Altogether, these findings are indicative of the manners in which different types of engineered biomaterial scaffolds can produce varying stem cell self-renewal or differentiation potentials. In addition to scaffolds, self-renewal of ES cells is maintained by incorporation of growth factors such as LIF [129] or bFGF [130], which will inherently induce greater cell expansion.

To closely imitate the specific types of biomolecules surrounding ES cells, the field of nanotechnology offers a potential solution through the creation of nanoparticles capable of delivering the necessary growth factors to stimulate stem cell proliferation or differentiation. For example, Tran and coworkers studied the influence of nanoparticles on mouse ES cell viability and differentiated morphology and discovered that mouse ES cells differentiate into different cell types, for example, fibroblast-like cells or embryoid bodies, depending on the concentration of the polystyrene nanoparticles in which they are exposed [141]. In reference to the neighboring cells of ES cells, the emergence of cellular patterning technology has yielded potential techniques for taking advantage of bioengineered ES cell microenvironments comprised of manufactured cell-cell interactions [144]. Specifically, this technology contributes to co-culture feasibility through the creation of a combinatorial library of cells that ordinarily exist in vivo. In addition, the possibility of investigating the influences of ES cell location and spatial proximity in relation to other types of cells has become tangible. Most importantly, mouse ES cells maintain their pluripotency after laser direct-write patterning and this particular finding reveals the mechanisms for exploitation of this technology in order to understand cellular interactions between ES cells and breast cancer cells. 


\section{Embryonic Microenvironment and Cancer}

\subsection{The Importance of Embryonic Microenvironments in Inhibiting Tumorigenesis}

The importance of the embryonic microenvironment in cancer progression and metastasis has been demonstrated in zebrafish, chick and mouse embryonic models [26,145-147]. Mintz \& Illmensee performed the initial study implying that exposure to the mouse embryonic microenvironment reprograms teratocarcinoma cells into cells capable of differentiating into normal cells [148]. Pierce et al. showed that embryonic microenvironments inhibit the tumorigenicity of embryonal carcinoma cancer cells [149]. Hendrix and colleagues performed multiple studies demonstrating that embryonic microenvironments prevent human melanoma cells from tumorigenesis after implantation into the embryo of zebrafish [150] or revert the metastatic melanoma phenotype to its cell type of origin in an embryonic chick model [24]. The capability of the embryonic microenvironment to inhibit tumorigenesis and reprogram metastatic cancer cells to a less aggressive phenotype was confirmed using an in vitro mouse embryo model [151] and intrauterine transplantation mouse model [152], respectively. These studies reveal the uniqueness of the embryonic microenvironment in halting tumorigenicity. For example, Patton et al. observed enhanced tumor growth when cancer cells were implanted in adult zebrafish as opposed to an embryonic microenvironment [153]. These findings are supported by Kasemeier-Kulesa et al., who reprogrammed human multipotent tumor cells into a benign phenotype when transplanted in a neural crest chick microenvironment [147]. All this evidence demonstrates the capacity of the embryonic microenvironment to either delay or reverse tumorigenesis, suggesting that embryonic microenvironments might contain factors that could inhibit cancer growth and metastasis.

\subsection{Convergence of Tumorigenic and Embryonic Signaling Pathways}

Embryonic signaling pathways such as Notch, Hedgehog (Hh), Wnt, and TGF- $\beta$, are responsible for initiating and driving EMT during embryogenesis [154,155]. These pathways are imperative in maintaining the highly-regulated ES cell processes of proliferation, differentiation, movement and polarity. Tumorigenic and embryonic signaling pathways cross paths during the course of EMT. Additionally, deregulation of embryonic signaling pathways is found in breast, pancreas, and lung tumors [45].

TGF- $\beta$ and $\mathrm{Wnt} / \beta$-catenin signaling pathways are misexpressed in breast cancer and associated with poor clinical outcomes $[37,38]$. The TGF- $\beta$ pathway activates Notch, Hh and Wnt signaling and plays an important role in the process of EMT, embryogenesis and tumorigenesis. Two main branches of the TGF- $\beta$ signaling pathway are SMAD $1 / 5 / 8$ and SMAD $2 / 3$. The former branch is mediated by the binding of BMP or GDF ligands to TGF- $\beta$ receptors ALK1, 2, 3, and 6 , whereas, the latter branch is mediated by the binding of Activin and Nodal ligands to TGF- $\beta$ receptors ALK4, 5, and 7 (Figure 1). The activation of TGF- $\beta$ signaling triggers the phosphorylation of SMADs which subsequently form complexes with SMAD that translocate to the nucleus and regulate gene expression. In this way, the induction of EMT via cell signaling proteins, SMAD3 and SMAD4, is activated by the TGF- $\beta$ pathway. Mutations and deregulation of TGF- $\beta$ receptors leading to inactivation of SMAD4 are observed in various cancers. Examples of TGF- $\beta$ inhibitors include Lefty A, Lefty B, Gremlin, 
Cerberus, Follistatin, and Chordin. The mechanism of Wnt signaling involves the binding of a Wnt ligand to the FRIZZLED receptor to activate Dishelved (Dsh) protein (Figure 1). Dsh inhibits GSK-3 which is responsible for $\beta$-catenin degradation. Upon Wnt activation, $\beta$-catenin accumulates in the cytoplasm and translocates to the nucleus where it interacts with the transcriptional factor T-cell Factor/Lymphocyte Enhancing Binding Factor (Tcf/Lef) [155]. In tumors, Wnt signaling is active and thus stabilizes $\beta$-catenin, whose binding to Tcf/Lef activates oncogenes of c-myc and cyclin D1 and stimulates tumor cell proliferation. Documented inhibitors of Wnt signaling include Dkk1, 3, sFRP, WIF-1 and Cerberus.

Figure 1. Schematics of TGF- $\beta$ and Wnt signaling pathways that show the cross-path in tumor and ES cell microenvironments. ES cells can secrete inhibitors of TGF- $\beta$ and Wnt to regulate the normal embryonic program.

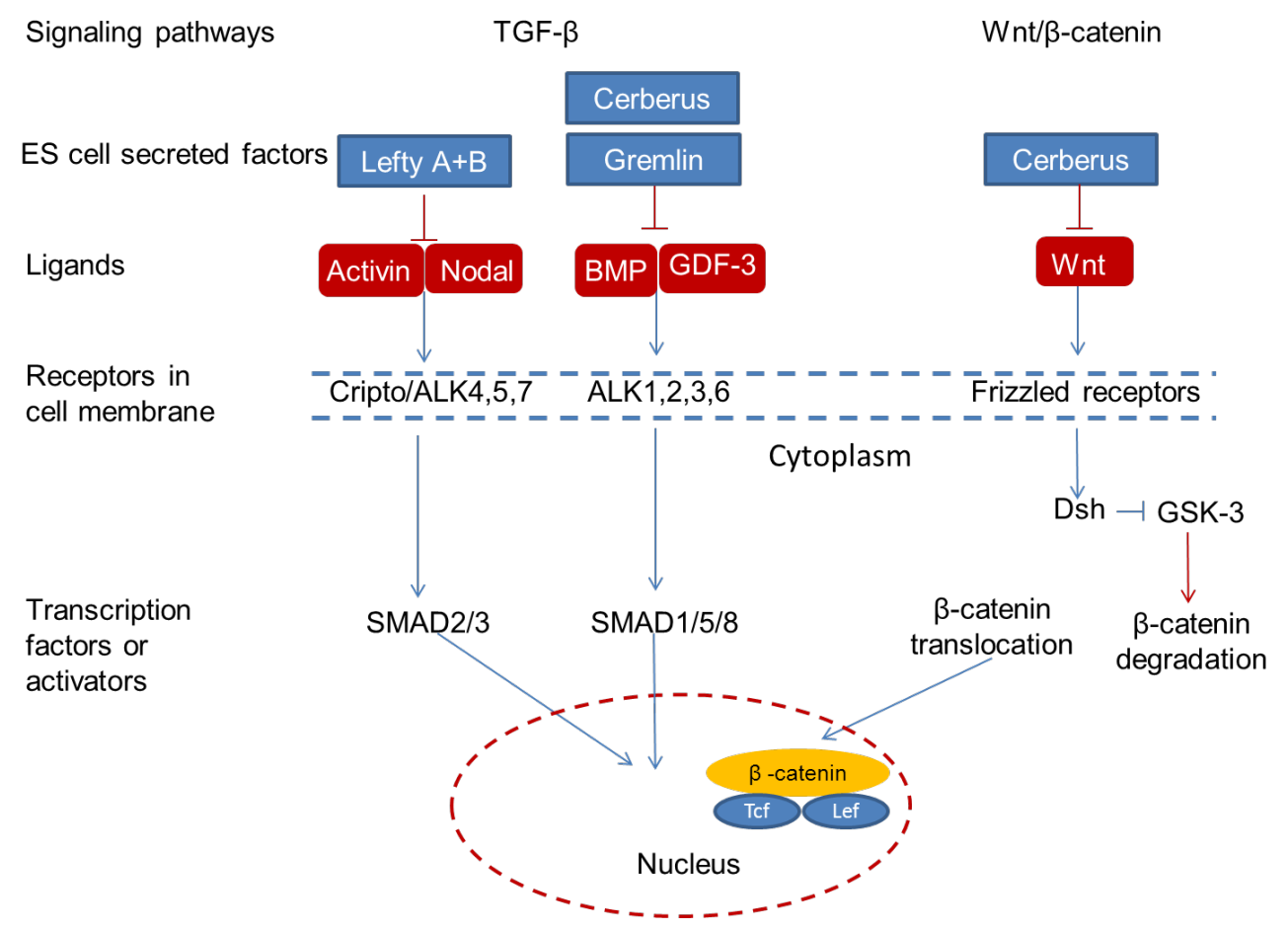

As previously mentioned, embryonic signaling pathways are tightly controlled in the ES cell microenvironment. Mutations occur within tumor and stromal cells in a tumor microenvironment. Breast tumor cells and ES cells secrete cytokines and chemokines to their microenvironment, however, breast cancer cells secrete a significantly higher level of soluble factors, which is correlated with tumor metastasis (e.g., M-CSF, OSM, MIP-2/CXCL-2, MMP-9, TIMP-1). Undifferentiated ES cells could secrete Lefty A, Lefty B, Gremlin, Cerberus, etc., which are inhibitors of TGF- $\beta$ and Wnt. Tumorigenic and embryonic microenvironments converge via TGF- $\beta$ and Wnt signaling pathways. However, deregulation of embryonic signaling pathways occurs and critical inhibitors to regulate normal embryonic pathways are missing in a tumor microenvironment. The ES cell microenvironments have great potential to supply critical signaling molecules and reprogram the abnormal embryonic signaling pathway in tumors. 


\subsection{Breast Cancer Stem Cells and Embryonic Stem Cell Microenvironment}

The recurrence of breast cancer accompanied with the manifestation of metastasis may be attributed to the presence of breast cancer stem cells (CSCs) within the tumor. Breast CSCs are a small subset of cells coexisting within the breast cancer cell population that have the ability to self-renew and to differentiate into heterogeneous cancer cells. The origin of breast CSCs is not fully understood but is thought to arise from a mutation that occurs during continuous stem cell division and replication. Al Hajj et al. are the first researchers to identify a subset of breast CSCs isolated directly from patients [156]. Their study demonstrates that only a small subset of $\mathrm{CD} 44^{+} / \mathrm{CD} 24^{-}$breast cancer cells is capable of driving carcinogenesis and possesses the ability to self-renew and to generate multiple cancer cell types. In addition to the $\mathrm{CD} 44^{+} / \mathrm{CD} 24^{-}$phenotype, other prominent biomarkers of breast CSCs include aldehyde hydrogenase (ADH)1 [157], CD49f, CD29, and CD133 [158]. Breast CSCs are also highly regulated by their complex and dynamic niche. Bidirectional communication between breast CSCs and their surroundings, such as neighboring cells (fibroblasts, endothelial cells, macrophages, mesenchymal stem cells, etc.) and soluble molecules (CXCL12, IL-6, IL-8, etc.) greatly influences cellular development. For instance, the cytokines IL-6 and CXCL7 are secreted from nearby mesenchymal stem cells resulting in the self-renewal of breast CSCs via the activation of STAT3/NFkB signaling [159]. Targeting the breast CSC niche may provide an alternative method to eradicate the source of breast cancer in order to prevent disease recurrence or metastasis $[160,161]$. Several excellent review papers on breast CSCs are referenced for readers interested in obtaining greater detail regarding this subject $[45,162,163]$.

Wong et al. elucidated an important aspect in reference to the relationship between breast CSCs and the ES cell microenvironment and reported that the ES cell-like gene module is activated in diverse human epithelial cancers, including liver, breast, prostate, gastric and lung cancer, where identification of an ESC-like signature is a powerful predictor of metastasis and death. In particular, c-Myc, rather than other oncogenes, is sufficient to reactivate the ES cell-like transcriptional program in normal and cancer cells [164]. Alternatively, Somervaille et al. implemented a leukemia stem cell model system to study the similarity of CSCs and ES cells. The researchers illustrated that CSCs share transcriptional regulators of self-renewal with ES cells, such as Hmgb3, Cbx5, Mtf2, and Orc21 [165]. However, this ES cell-like state in CSCs is not mediated by the upstream regulators Nanog, Oct4, or Sox2, which are essential transcription factors for maintaining the pluripotency of ES cells. Furthermore, it is predicted that the poor prognosis of human malignancies is caused by an inappropriate expression of upstream regulators linked with a down-stream ES-like program for aberrant self-renewal of ESCs. Therefore, ES cells self-renew in a highly regulated manner, whereas CSCs self-renew in a poorly controlled manner. This study supports the notion that restoring the normal niche of the ES cell microenvironment may cause breast CSCs to convert to a benign phenotype.

Breast CSCs also employ embryonic signaling pathways in order to commence EMT for the occurrence of metastasis. However, unlike embryogenesis, metastasis is driven by transformation of embryonic pathways. Considering the heavy involvement of these altered embryonic pathways in driving metastasis, it is clear that targeting them is a promising approach in treating breast cancer. We hope that replacing the breast CSC microenvironments with a normal ES cell niche may alleviate the deregulation of embryonic pathways, which in turn will restrict metastatic disease. 


\subsection{Reprogramming of Metastatic Cancer Cells Using ES Cell-Conditioned Microenvironments}

A state of the art technique for examining the potential ability of ES cell-conditioned microenvironments to cease cancer cell growth involves hES cell-conditioned Matrigel and was performed by Hendrix's group. This research demonstrated that hES cell-conditioned Matrigel reprograms metastatic melanoma cells to a less aggressive phenotype and significantly inhibits invasiveness and tumorigenesis [166]. Most of these in vivo and in vitro studies focus on melanoma cells. At this point, only two studies have investigated the effects of human ES cell-conditioned Matrigels on human breast cancer cells. Postovit et al. showed that cancer cells overexpress Nodal genes, the embryonic morphogen expressed in hES cells. Basically, these genes are responsible for the maintenance of pluripotency in ES cells and tumorigenesis in cancer cells. The expression of these genes is regulated by Lefty, an inhibitor of the Nodal signaling pathway. However, Lefty is not expressed in breast cancer cells or their microenvironments. As shown in Figure 1, exposure of cancer cells to the ES cell-conditioned Matrigel (containing Lefty) could suppress Nodal gene expression in cancer cells leading to apoptosis, which is significant because recombinant Lefty is unable to downregulate Nodal [23]. This finding is directly attributed to the fact that the ES cell microenvironment-derived Lefty was glycosylated and more physiologically active in comparison to recombinant Lefty. In addition to Nodal knock-down, they also observed the down regulation of VE-Cadherin (a tumor angiogenesis marker) after the exposure of human melanoma cells to hES cell-conditioned Matrigel [167]. Subsequent studies performed by this group have offered additional factors within the human ES cell microenvironment that potentially contribute to epigenetic reprogramming of metastatic tumor cells such as DNA methylation and microRNA regulation [22].

Kim et al. further clarified the implementation of a mouse ES-conditioned Matrigel to inhibit human melanoma cells. Their findings highlighted the discovery of an important factor in the ES cell microenvironment responsible for halting cancer cell proliferation, Gremlin. Gremlin is an antagonist of bone morphogenetic protein 4 (BMP4) that regulates stem cell expansion and differentiation. As shown in Figure 1, the presence of Gremlin induces cellular senescence in melanoma cancer cells [25]. Another study by Ben-Porath et al. revealed that poorly differentiated tumor cells consist of genes that are highly expressed in human ES cells such as Nanog, Oct4, Sox2 and c-myc as compared to well differentiated tumor cells [168]. The relationship between human ES cell conditioned medium and human epithelial, ovarian, prostate and breast cancer cell proliferation was assessed by Giuffrida et al. [21]. In their study, cancer cell proliferation decreases after exposure to human ES cell-conditioned media as compared to the controls containing mouse fibroblast conditioned media and normal cancer cell media. Dilution studies demonstrated that depletion of nutrients in human ES cell-conditioned medium does not contribute to the arrest of cancer cell proliferation [21]. This study confirms that hES cells secrete factors smaller than $10 \mathrm{kD}$ which plays a major role in inhibiting cell proliferation and terminating the cell cycle. Referring to Table 1, which contains a list of cytokines released from undifferentiated murine ES cells, it is apparent that chemokines are factors that typically have molecular weights less than $10 \mathrm{kD}$ and play a critical role in inhibiting cancer cell proliferation (Figure 2). These findings implicate ES cell-derived active microenvironments as important sources of tumor suppression factors, which are summarized in Table 2. 
Figure 2. Schematics of the interactions of embryonic stem (ES) cell microenvironments and cancer cells.

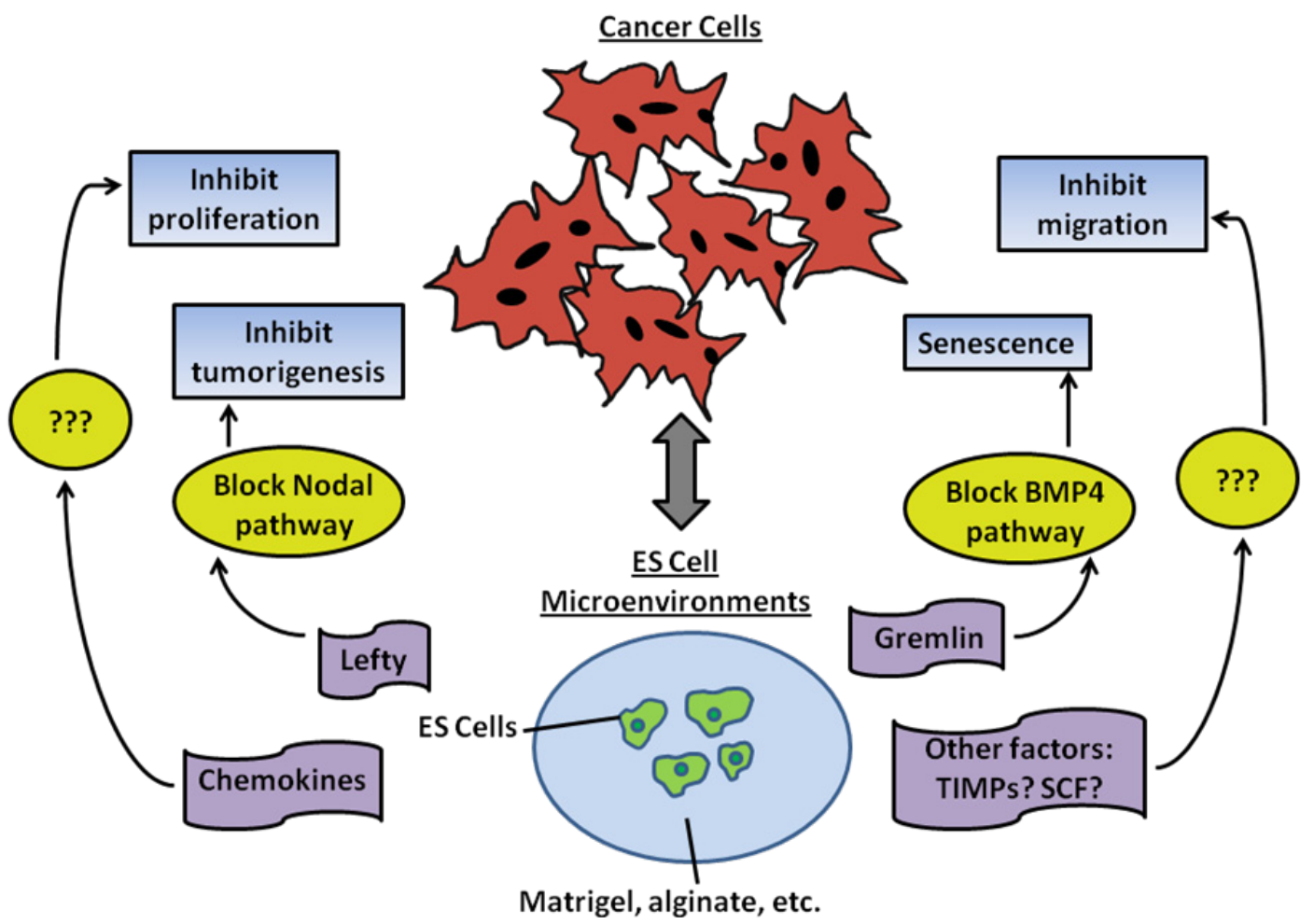

Table 2. State of the art research regarding the utilization of embryonic microenvironments to understand and inhibit cancer metastasis.

\begin{tabular}{|c|c|c|c|}
\hline $\begin{array}{l}\text { Embryonic } \\
\text { Microenvironments }\end{array}$ & Cancer Cells & Effects & References \\
\hline $\begin{array}{l}\text { Zebrafish embryo } \\
\text { model }\end{array}$ & $\begin{array}{l}\text { Human metastatic } \\
\text { melanoma cells }\end{array}$ & $\begin{array}{l}\text { Support cell survival and division } \\
\text { with no tumor formation. }\end{array}$ & [150] \\
\hline $\begin{array}{l}\text { Embryonic chick } \\
\text { model }\end{array}$ & $\begin{array}{l}\text { Human metastatic } \\
\text { melanoma cells }\end{array}$ & $\begin{array}{l}\text { Revert the metastatic phenotype to } \\
\text { its cell type of origin. }\end{array}$ & {$[24]$} \\
\hline $\begin{array}{l}\text { hESC-conditioned } \\
\text { Matrigel }\end{array}$ & $\begin{array}{l}\text { Human metastatic } \\
\text { melanoma cells }\end{array}$ & $\begin{array}{l}\text { Induce a melanocyte-like } \\
\text { phenotype and significantly inhibit } \\
\text { the in vitro invasiveness of cancer } \\
\text { cells. }\end{array}$ & {$[166]$} \\
\hline $\begin{array}{l}\text { hESC-conditioned } \\
\text { Matrigel }\end{array}$ & $\begin{array}{l}\text { Human metastatic } \\
\text { melanoma and } \\
\text { breast cancer cells }\end{array}$ & $\begin{array}{l}\text { Decrease Nodal expression and } \\
\text { inhibit tumorigenesis. }\end{array}$ & {$[23]$} \\
\hline $\begin{array}{l}\text { hESC-conditioned } \\
\text { Matrigel }\end{array}$ & $\begin{array}{l}\text { Human metastatic } \\
\text { melanoma cells }\end{array}$ & Decrease VE-Cadherin expression. & {$[167]$} \\
\hline $\begin{array}{l}\text { hESC-conditioned } \\
\text { Matrigel }\end{array}$ & $\begin{array}{l}\text { Human metastatic } \\
\text { melanoma cells }\end{array}$ & $\begin{array}{l}\text { Identify miRNAs up- and } \\
\text { down- regulated in reprogramming } \\
\text { of melanoma cells. }\end{array}$ & {$[22]$} \\
\hline $\begin{array}{l}\text { mESC-conditioned } \\
\text { Matrigel }\end{array}$ & $\begin{array}{l}\text { Human metastatic } \\
\text { melanoma and } \\
\text { breast cancer cells }\end{array}$ & $\begin{array}{l}\text { Inhibit cell proliferation, decrease } \\
\text { anchorage independence and induce } \\
\text { senescence. }\end{array}$ & {$[25]$} \\
\hline
\end{tabular}


Table 2. Cont.

\begin{tabular}{lllc}
\hline $\begin{array}{l}\text { Embryonic } \\
\text { Microenvironments }\end{array}$ & Cancer Cells & Effects & References \\
\hline $\begin{array}{l}\text { hESC-conditioned } \\
\text { medium }\end{array}$ & $\begin{array}{l}\text { Human epithelial } \\
\text { ovarian, prostate, } \\
\text { and breast cancer } \\
\text { cells }\end{array}$ & $\begin{array}{l}\text { Inhibit cell proliferation and cell } \\
\text { cycle (increased cells in G1 and } \\
\text { deceased cells in S and G2/M } \\
\text { phase). }\end{array}$ & {$[21]$} \\
\hline $\begin{array}{l}\text { In vitro mouse } \\
\text { embryo model }\end{array}$ & $\begin{array}{l}\text { Human melanoma } \\
\text { cells }\end{array}$ & $\begin{array}{l}\text { Support the melanoma cell } \\
\text { migration inside the embryo model } \\
\text { in a way reminiscent of neural crest } \\
\text { cells with no tumor growth. }\end{array}$ & {$[151]$} \\
\hline $\begin{array}{l}\text { Bioengineered mESC } \\
\text { microenvironment }\end{array}$ & $\begin{array}{l}\text { Rat metastatic } \\
\text { breast cancer cells }\end{array}$ & $\begin{array}{l}\text { Inhibit the growth and migration of } \\
\text { breast cancer cells. }\end{array}$ & {$[169]$} \\
\hline
\end{tabular}

\subsection{Bioengineered Embryonic Microenvironments for Breast Cancer Research}

Most of the previously described experiments demonstrated "state of the art" techniques for exploring the embryonic microenvironment and were analyzed to determine if it is possible to arrest cancer cell proliferation and reprogram metastatic cancer cells using in vivo microenvironments or ES cell-conditioned Matrigel. In addition, the majority of these studies focused on human metastatic melanoma cells. The limited research related to the exploitation of in vitro dynamic embryonic microenvironments in an effort to understand and inhibit breast cancer metastasis prompted further investigation. In our lab, we have explored the possibility of using 3D bioengineered embryonic microenvironments consisting of alginate hydrogel and mouse ES cells to examine the possibility of dynamically reversing malignant growth and migration of metastatic breast cancer cells.

Bioengineered 3D in vitro models for studying dynamic ES cell-cancer cell interactions can bridge the gap between 2D cell cultures and whole-animal systems. Cancer cells cultured in 3D alginate hydrogel are capable of forming multicellular tumor spheroids [170-173]. The 3D microenvironment recapitulates the native setting and permits tumorigenesis as compared to $2 \mathrm{D}$ [174]. Alginate, obtained from cell walls of brown algae, is an anionic polysaccharide that consists of $\beta$-D-mannuronate and $\alpha$-L-guluronate residues $[175,176]$. In the past, it has been broadly utilized in tissue engineering and regenerative medicine due to its biocompatibility, as well as, gentle gelling behavior. In addition, the ability of alginate to retain a large quantity of water mimics glycosaminoglycans (GAG), which are a component of the ECM. [177,178] Analogous to GAG, alginate is a negatively charged polysaccharide with a high viscosity that could also provide a good platform and structural integrity to allow for smooth cell migration. One method of forming alginate hydrogel is through exposure of the alginate solution to divalent cations such as calcium chloride, barium chloride, and zinc chloride. Cells are encapsulated in alginate hydrogel by combining them with the alginate solution prior to exposure to divalent cations. Alginate hydrogel is further coated with poly-L-lysine to modify its microenvironment from gelled to aqueous via a chelating agent such as sodium citrate. The encapsulation technology employing alginate hydrogel has been successfully performed in studies related to various types of systems such as stem cell differentiation [179-183], pancreatic islets delivery for diabetes treatment [184-187] as well as 3D disease models [188,189]. 
ES cells were encapsulated in alginate hydrogel microbeads via an electrostatic-driven method. The cells were allowed to grow within the microbeads creating an in vitro bioengineered embryonic microenvironment [169]. ES cells in alginate hydrogels remained in an undifferentiated state, which supports their self-renewal and pluripotency. The co-encapsulation of ES cells with metastatic breast cancer cells in aqueous alginate microbeads displayed inhibition of tumor formation as opposed to encapsulation of breast cancer cells alone. Further studies involved the exposure of alginate hydrogel microbeads laden with ES cells to highly invasive breast cancer cells to examine the effects on cancer cell proliferation and migration. ES cells were encapsulated in alginate hydrogel microbeads (about $600 \mu \mathrm{m}$ in diameter) at initial cell densities of $10^{5}, 3 \times 10^{5}, 5 \times 10^{5}$ and $10^{6} \mathrm{cells} / \mathrm{mL}$ alginate. The corresponding cell numbers in each microbead were 11, 34, 56 and 113 cells, respectively. Only one bead containing ES cells was added to metastatic breast cancer cells. Following co-culture for 1-2 days, the proliferation levels of metastatic breast cancer cells was examined. We discovered that microbeads containing 113 ES cells (equivalent to $10^{6}$ cells $/ \mathrm{mL}$ alginate) displayed the highest level of cancer cell proliferation inhibition on day one, while all types of microbeads inhibited cancer cell proliferation by day two. Therefore, we employed the initial cell density of $10^{6}$ cells $/ \mathrm{mL}$ alginate for all future studies. One, two, five or ten microbeads containing ES cells were co-cultured with metastatic breast cancer cells. After two days of cultivation, five microbeads containing the 113 cells/bead exhibited the maximum inhibitory effect on the proliferation of metastatic breast cancer cells. The inhibition rate of cell proliferation was over $90 \%$. In particular, the migration of cancer cells was monitored and analyzed using image $\mathbf{J}$ software in the absence or presence of ES cells or NIH 3T3 fibroblasts. To quantify the speed of cell migration, the average velocity was calculated as the mean of all the values of velocity for an individual cell during a 4 hour imaging course. Compared to the control group (metastatic breast cancer cells alone), ES cells in hydrogel significantly restricted the growth and migration of metastatic breast cancer cells while hydrogel microbeads containing NIH 3T3 fibroblasts did not influence these two factors significantly (Figure 3). Based on the results obtained through the measurement of breast cancer cell proliferation and quantification of cell migration after the co-culture, we conclude that mouse ES cells encapsulated in alginate hydrogel microbeads may have secreted soluble factors that inhibit metastatic breast cancer cell growth and migration [169]. This bioengineered embryonic microenvironment provides a new avenue for identifying anti-tumor/anti-metastasis factors to restrict the proliferative capacity and metastatic potential of tumor cells. Elucidation of key components will lead to the creation of bioengineered microenvironments that can restrict metastatic disease progression. Mimicking the embryonic microenvironment to reprogram metastatic cancer cells to less invasive phenotype has great potential to transform the ways in which cancer is treated in the future. 
Figure 3. Inhibitory effects of bioengineered ES cell microenvironments on metastatic cancer cells. (a) Cell proliferation; (b) Cell migration. Mouse ES cells in 3D alginate hydrogel beads (3D-ESC) significantly inhibited the proliferation and migration of metastatic breast cancer cells while NIH 3T3 fibroblasts in 3D alginate hydrogel beads (3D-3T3) did not display the significant inhibitory effect. $* * * p<0.001$. **** $p<0.0001$.
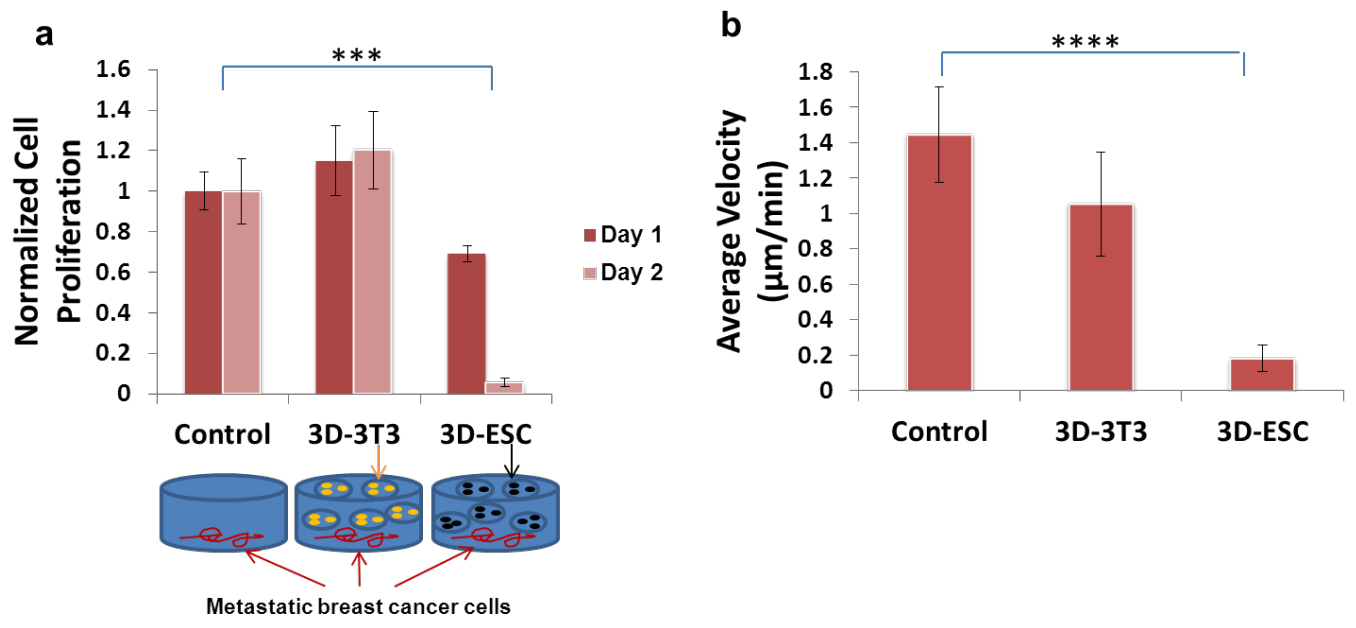

\section{Outlook}

Metastatic cancer cells interact dynamically with a microenvironment that facilitates plasticity, tumorigenicity and metastasis. The unique microenvironment of breast cancer cells plays an important role in the regulation of metastasis. The engineering of cancer cell microenvironments in vitro may allow improved study of breast cancer metastasis leading to the discovery of a mechanism that will reverse malignant tumor growth. Metastatic cancer cells and CSCs share aspects of their transcriptional program with ES cells and employ embryonic signaling pathways to drive EMT process. The presence of an ES cell-like gene signature is correlated to poor clinical outcome because the critical molecular messengers are aberrantly expressed in tumor cells and inhibitors are missing in tumor microenvironments. Microenvironments of undifferentiated ES cells have the potential to restrict tumor cell growth and metastasis, as they might supply molecular messengers or inhibitors to regulate or reprogram the abnormal embryonic signaling pathway and restore normalcy. Recent findings from our lab have demonstrated the capacity of a bioengineered embryonic microenvironment to inhibit breast cancer metastasis, proving its potential in identifying anti-tumor/anti-metastasis factors as well as restricting metastatic disease. In the future, human embryonic stem cells and metastatic breast cancer cells or cancer stem cells will be employed in this system as it is more clinically relevant. In addition, it is essential to explore the feasibility of using induced pluripotent stem (iPS) cells to create an in vitro embryonic microenvironment. We anticipate that a more in-depth understanding of ES cell-breast cancer cell interactions will lead to the prevention and treatment of breast cancer metastasis.

\section{Acknowledgements}

This material is based upon work supported by the National Science Foundation under Grant No. CBET 0846270, EEC 0914790 and DBI 0922830. 


\section{References}

1. Siegel, R.; Ward, E.; Brawley, O.; Jemal, A. Cancer statistics, 2011: The impact of eliminating socioeconomic and racial disparities on premature cancer deaths. CA Cancer J. Clin. 2011, 61, $212-236$.

2. Gluck, S. The prevention and management of distant metastases in women with breast cancer. Cancer Invest. 2007, 25, 6-13.

3. Mehlen, P.; Puisieux, A. Metastasis: A question of life or death. Nat. Rev. Cancer 2006, 6, 449-458.

4. Finger, E.C.; Giaccia, A.J. Hypoxia, inflammation, and the tumor microenvironment in metastatic disease. Cancer Metastasis Rev. 2010, 29, 285-293.

5. Chaffer, C.L.; Weinberg, R.A. A perspective on cancer cell metastasis. Science 2011, 331, $1559-1564$.

6. Bissell, M.J.; Labarge, M.A. Context, tissue plasticity, and cancer: Are tumor stem cells also regulated by the microenvironment? Cancer Cell 2005, 7, 17-23.

7. Weigelt, B.; Bissell, M.J. Unraveling the microenvironmental influences on the normal mammary gland and breast cancer. Semin. Cancer Biol. 2008, 18, 311-321.

8. Ma, X.J.; Dahiya, S.; Richardson, E.; Erlander, M.; Sgroi, D.C. Gene expression profiling of the tumor microenvironment during breast cancer progression. Breast Cancer Res. 2009, 11, R7:1-R7:18.

9. Carlini, M.J.; de Lorenzo, M.S.; Puricelli, L. Cross-talk between tumor cells and the microenvironment at the metastatic niche. Curr. Pharm. Biotechnol. 2011, in press.

10. Croci, D.; Salatino, M. Tumor immune escape mechanisms that operate during metastasis. Curr. Pharm. Biotechnol. 2011, in press.

11. Joyce, J.A.; Pollard, J.W. Microenvironmental regulation of metastasis. Nat. Rev. Cancer 2009, 9, 239-252.

12. Barbolina, M.V.; Moss, N.M.; Westfall, S.D.; Liu, Y.; Burkhalter, R.J.; Marga, F.; Forgacs, G.; Hudson, L.G.; Stack, M.S. Microenvironmental regulation of ovarian cancer metastasis. Cancer Treat. Res. 2009, 149, 319-334.

13. Lathia, J.D.; Heddleston, J.M.; Venere, M.; Rich, J.N. Deadly teamwork: Neural cancer stem cells and the tumor microenvironment. Cell Stem Cell 2011, 8, 482-485.

14. Jagannathan, N.R.; Bhujwalla, Z.M. Tumor microenvironment in cancer treatment and metastasis. NMR Biomed. 2011, 24, 559-560.

15. Cichon, M.A.; Degnim, A.C.; Visscher, D.W.; Radisky, D.C. Microenvironmental influences that drive progression from benign breast disease to invasive breast cancer. J. Mammary Gland Biol. Neoplasia 2010, 15, 389-397.

16. Malchenko, S.; Galat, V.; Seftor, E.A.; Vanin, E.F.; Costa, F.F.; Seftor, R.E.; Soares, M.B.; Hendrix, M.J. Cancer hallmarks in induced pluripotent cells: New insights. J. Cell. Physiol. 2010, 225, 390-393.

17. Topczewska, J.M.; Postovit, L.M.; Margaryan, N.V.; Sam, A.; Hess, A.R.; Wheaton, W.W.; Nickoloff, B.J.; Topczewski, J.; Hendrix, M.J. Embryonic and tumorigenic pathways converge via nodal signaling: Role in melanoma aggressiveness. Nat. Med. 2006, 12, 925-932. 
18. Abbott, D.E.; Postovit, L.M.; Seftor, E.A.; Margaryan, N.V.; Seftor, R.E.; Hendrix, M.J. Exploiting the convergence of embryonic and tumorigenic signaling pathways to develop new therapeutic targets. Stem Cell Rev. 2007, 3, 68-78.

19. Postovit, L.M.; Costa, F.F.; Bischof, J.M.; Seftor, E.A.; Wen, B.; Seftor, R.E.; Feinberg, A.P.; Soares, M.B.; Hendrix, M.J. The commonality of plasticity underlying multipotent tumor cells and embryonic stem cells. J. Cell. Biochem. 2007, 101, 908-917.

20. Ingber, D.E. Can cancer be reversed by engineering the tumor microenvironment? Semin. Cancer Biol. 2008, 18, 356-364.

21. Giuffrida, D.; Rogers, I.M.; Nagy, A.; Calogero, A.E.; Brown, T.J.; Casper, R.F. Human embryonic stem cells secrete soluble factors that inhibit cancer cell growth. Cell Prolif. 2009, 42, 788-798.

22. Costa, F.F.; Seftor, E.A.; Bischof, J.M.; Kirschmann, D.A.; Strizzi, L.; Arndt, K.; de Fatima Bonaldo, M.; Soares, M.B.; Hendrix, M.J. Epigenetically reprogramming metastatic tumor cells with an embryonic microenvironment. Epigenomics 2009, 1, 387-398.

23. Postovit, L.M.; Margaryan, N.V.; Seftor, E.A.; Kirschmann, D.A.; Lipavsky, A.; Wheaton, W.W.; Abbott, D.E.; Seftor, R.E.; Hendrix, M.J. Human embryonic stem cell microenvironment suppresses the tumorigenic phenotype of aggressive cancer cells. Proc. Natl. Acad. Sci. USA 2008, 105, 4329-4334.

24. Kulesa, P.M.; Kasemeier-Kulesa, J.C.; Teddy, J.M.; Margaryan, N.V.; Seftor, E.A.; Seftor, R.E.; Hendrix, M.J. Reprogramming metastatic melanoma cells to assume a neural crest cell-like phenotype in an embryonic microenvironment. Proc. Natl. Acad. Sci. USA 2006, 103, 3752-3757.

25. Kim, M.O.; Kim, S.H.; Oi, N.; Lee, M.H.; Yu, D.H.; Kim, D.J.; Cho, E.J.; Bode, A.M.; Cho, Y.Y.; Bowden, T.G.; et al. Embryonic stem-cell-preconditioned microenvironment induces loss of cancer cell properties in human melanoma cells. Pigment Cell Melanoma Res. 2011, 24, 922-931.

26. Tzukerman, M.; Rosenberg, T.; Reiter, I.; Ben-Eliezer, S.; Denkberg, G.; Coleman, R.; Reiter, Y.; Skorecki, K. The influence of a human embryonic stem cell-derived microenvironment on targeting of human solid tumor xenografts. Cancer Res. 2006, 66, 3792-3801.

27. Wang, Z.; Zhang, L.; Yeung, T.K.; Chen, X. Endocytosis deficiency of epidermal growth factor (egf) receptor-erbb2 heterodimers in response to egf stimulation. Mol. Biol. Cell 1999, 10, 1621-1636.

28. Caldon, C.E.; Sutherland, R.L.; Musgrove, E. Cell cycle proteins in epithelial cell differentiation: Implications for breast cancer. Cell Cycle 2010, 9, 1918-1928.

29. Lee, E.Y.; Muller, W.J. Oncogenes and tumor suppressor genes. Cold Spring Harb. Perspect. Biol. 2010, 2, a003236.

30. Hollestelle, A.; Nagel, J.H.; Smid, M.; Lam, S.; Elstrodt, F.; Wasielewski, M.; Ng, S.S.; French, P.J.; Peeters, J.K.; Rozendaal, M.J.; et al. Distinct gene mutation profiles among luminal-type and basal-type breast cancer cell lines. Breast Cancer Res. Treat. 2010, 121, 53-64.

31. Mackay, A.; Tamber, N.; Fenwick, K.; Iravani, M.; Grigoriadis, A.; Dexter, T.; Lord, C.J.; Reis-Filho, J.S.; Ashworth, A. A high-resolution integrated analysis of genetic and expression profiles of breast cancer cell lines. Breast Cancer Res. Treat. 2009, 118, 481-498. 
32. Kao, J.; Salari, K.; Bocanegra, M.; Choi, Y.L.; Girard, L.; Gandhi, J.; Kwei, K.A.; Hernandez-Boussard, T.; Wang, P.; Gazdar, A.F.; et al. Molecular profiling of breast cancer cell lines defines relevant tumor models and provides a resource for cancer gene discovery. PLoS One 2009, 4, e6146:1-e6146:16.

33. Kessenbrock, K.; Plaks, V.; Werb, Z. Matrix metalloproteinases: Regulators of the tumor microenvironment. Cell 2010, 141, 52-67.

34. Herrera-Gayol, A.; Jothy, S. Adhesion proteins in the biology of breast cancer: Contribution of cd44. Exp. Mol. Pathol. 1999, 66, 149-156.

35. Sethi, S.; Sarkar, F.H.; Ahmed, Q.; Bandyopadhyay, S.; Nahleh, Z.A.; Semaan, A.; Sakr, W.; Munkarah, A.; Ali-Fehmi, R. Molecular markers of epithelial-to-mesenchymal transition are associated with tumor aggressiveness in breast carcinoma. Transl. Oncol. 2011, 4, 222-226.

36. Taherian, A.; Li, X.; Liu, Y.; Haas, T.A. Differences in integrin expression and signaling within human breast cancer cells. BMC Cancer 2011, 11, 293:1-293:15.

37. Creighton, C.J.; Chang, J.C.; Rosen, J.M. Epithelial-mesenchymal transition (emt) in tumor-initiating cells and its clinical implications in breast cancer. J. Mammary Gland Biol. Neoplasia 2010, 15, 253-260.

38. Micalizzi, D.S.; Farabaugh, S.M.; Ford, H.L. Epithelial-mesenchymal transition in cancer: Parallels between normal development and tumor progression. J. Mammary Gland Biol. Neoplasia 2010, 15, 117-134.

39. Chen, J.; Yao, Y.; Gong, C.; Yu, F.; Su, S.; Liu, B.; Deng, H.; Wang, F.; Lin, L.; Yao, H.; et al. Ccl18 from tumor-associated macrophages promotes breast cancer metastasis via pitpnm3. Cancer Cell 2011, 19, 541-555.

40. Li, J.Y.; Ou, Z.L.; Yu, S.J.; Gu, X.L.; Yang, C.; Chen, A.X.; Di, G.H.; Shen, Z.Z.; Shao, Z.M. The chemokine receptor ccr4 promotes tumor growth and lung metastasis in breast cancer. Breast Cancer Res. Treat. 2011, in press.

41. Johnson-Holiday, C.; Singh, R.; Johnson, E.; Singh, S.; Stockard, C.R.; Grizzle, W.E.; Lillard, J.W., Jr. Ccl25 mediates migration, invasion and matrix metalloproteinase expression by breast cancer cells in a ccr9-dependent fashion. Int. J. Oncol. 2011, 38, 1279-1285.

42. Allinen, M.; Beroukhim, R.; Cai, L.; Brennan, C.; Lahti-Domenici, J.; Huang, H.; Porter, D.; $\mathrm{Hu}, \mathrm{M}$; Chin, L.; Richardson, A.; et al. Molecular characterization of the tumor microenvironment in breast cancer. Cancer Cell 2004, 6, 17-32.

43. Patsialou, A.; Wyckoff, J.; Wang, Y.; Goswami, S.; Stanley, E.R.; Condeelis, J.S. Invasion of human breast cancer cells in vivo requires both paracrine and autocrine loops involving the colony-stimulating factor-1 receptor. Cancer Res. 2009, 69, 9498-9506.

44. Sarrio, D.; Rodriguez-Pinilla, S.M.; Hardisson, D.; Cano, A.; Moreno-Bueno, G.; Palacios, J. Epithelial-mesenchymal transition in breast cancer relates to the basal-like phenotype. Cancer Res. 2008, 68, 989-997.

45. Takebe, N.; Warren, R.Q.; Ivy, S.P. Breast cancer growth and metastasis: Interplay between cancer stem cells, embryonic signaling pathways and epithelial-to-mesenchymal transition. Breast Cancer Res. 2011, 13, doi:10.1186/bcr2876.

46. Wu, Y.; Zhou, B.P. Tnf-alpha/nf-kappab/snail pathway in cancer cell migration and invasion. Br. J. Cancer 2010, 102, 639-644. 
47. Weaver, A.M. Invadopodia: Specialized cell structures for cancer invasion. Clin. Exp. Metastasis 2006, 23, 97-105.

48. Jiang, P.; Enomoto, A.; Takahashi, M. Cell biology of the movement of breast cancer cells: Intracellular signalling and the actin cytoskeleton. Cancer Lett. 2009, 284, 122-130.

49. Bae, Y.H.; Ding, Z.; Das, T.; Wells, A.; Gertler, F.; Roy, P. Profilin1 regulates pi(3,4)p2 and lamellipodin accumulation at the leading edge thus influencing motility of mda-mb-231 cells. Proc. Natl. Acad. Sci. USA 2010, 107, 21547-21552.

50. Bae, Y.H.; Ding, Z.; Zou, L.; Wells, A.; Gertler, F.; Roy, P. Loss of profilin-1 expression enhances breast cancer cell motility by ena/vasp proteins. J. Cell. Physiol. 2009, 219, 354-364.

51. Gertler, F.; Condeelis, J. Metastasis: Tumor cells becoming menacing. Trends Cell Biol. 2011, 21, 81-90.

52. Yilmaz, M.; Christofori, G. Mechanisms of motility in metastasizing cells. Mol. Cancer Res. 2010, 8, 629-642.

53. Sahai, E. Illuminating the metastatic process. Nat. Rev. Cancer 2007, 7, 737-749.

54. Longatto Filho, A.; Lopes, J.M.; Schmitt, F.C. Angiogenesis and breast cancer. J. Oncol. 2010, 2010, 576384:1-576384:7.

55. Carpini, J.D.; Karam, A.K.; Montgomery, L. Vascular endothelial growth factor and its relationship to the prognosis and treatment of breast, ovarian, and cervical cancer. Angiogenesis 2010, 13, 43-58.

56. Chakraborty, G.; Rangaswami, H.; Jain, S.; Kundu, G.C. Hypoxia regulates cross-talk between syk and lck leading to breast cancer progression and angiogenesis. J. Biol. Chem. 2006, 281, 11322-11331.

57. Pollard, J.W. Macrophages define the invasive microenvironment in breast cancer. J. Leukoc. Biol. 2008, 84, 623-630.

58. Ronnov-Jessen, L.; Bissell, M.J. Breast cancer by proxy: Can the microenvironment be both the cause and consequence? Trends Mol. Med. 2009, 15, 5-13.

59. McSherry, E.A.; Donatello, S.; Hopkins, A.M.; McDonnell, S. Molecular basis of invasion in breast cancer. Cell. Mol. Life Sci. 2007, 64, 3201-3218.

60. $\mathrm{Hu}, \mathrm{M}$; Polyak, K. Molecular characterisation of the tumour microenvironment in breast cancer. Eur. J. Cancer 2008, 44, 2760-2765.

61. Radisky, E.S.; Radisky, D.C. Matrix metalloproteinase-induced epithelial-mesenchymal transition in breast cancer. J. Mammary Gland Biol. Neoplasia 2010, 15, 201-212.

62. Kohrmann, A.; Kammerer, U.; Kapp, M.; Dietl, J.; Anacker, J. Expression of matrix metalloproteinases (mmps) in primary human breast cancer and breast cancer cell lines: New findings and review of the literature. BMC Cancer 2009, 9, 188:1-188:20.

63. Bostrom, P.; Soderstrom, M.; Vahlberg, T.; Soderstrom, K.O.; Roberts, P.J.; Carpen, O.; Hirsimaki, P. Mmp-1 expression has an independent prognostic value in breast cancer. $B M C$ Cancer 2011, 11, 348:1-348:8.

64. Choi, J.Y.; Jang, Y.S.; Min, S.Y.; Song, J.Y. Overexpression of mmp-9 and hif-1alpha in breast cancer cells under hypoxic conditions. J. Breast Cancer 2011, 14, 88-95. 
65. Zhang, B.; Liu, Y.X.; Cao, W.F.; Cao, X.C.; Ning, L.S.; Hao, X.S. Relationship between the expression of matrix metalloproteinase-13 protein and other biomarkers, prognosis in invasive breast cancer. Zhonghua Bing Li Xue Za Zhi 2008, 37, 471-476.

66. Stark, A.M.; Anuszkiewicz, B.; Mentlein, R.; Yoneda, T.; Mehdorn, H.M.; Held-Feindt, J. Differential expression of matrix metalloproteinases in brain- and bone-seeking clones of metastatic mda-mb-231 breast cancer cells. J. Neurooncol. 2007, 81, 39-48.

67. Denhardt, D.T.; Feng, B.; Edwards, D.R.; Cocuzzi, E.T.; Malyankar, U.M. Tissue inhibitor of metalloproteinases (timp, aka epa): Structure, control of expression and biological functions. Pharmacol. Ther. 1993, 59, 329-341.

68. Nguyen, Q.; Willenbrock, F.; Cockett, M.I.; O’Shea, M.; Docherty, A.J.; Murphy, G. Different domain interactions are involved in the binding of tissue inhibitors of metalloproteinases to stromelysin-1 and gelatinase a. Biochemistry 1994, 33, 2089-2095.

69. Vempati, P.; Karagiannis, E.D.; Popel, A.S. A biochemical model of matrix metalloproteinase 9 activation and inhibition. J. Biol. Chem. 2007, 282, 37585-37596.

70. O’Connell, J.P.; Willenbrock, F.; Docherty, A.J.; Eaton, D.; Murphy, G. Analysis of the role of the cooh-terminal domain in the activation, proteolytic activity, and tissue inhibitor of metalloproteinase interactions of gelatinase b. J. Biol. Chem. 1994, 269, 14967-14973.

71. Knauper, V.; Lopez-Otin, C.; Smith, B.; Knight, G.; Murphy, G. Biochemical characterization of human collagenase-3. J. Biol. Chem. 1996, 271, 1544-1550.

72. Stratmann, B.; Farr, M.; Tschesche, H. Characterization of c-terminally truncated human tissue inhibitor of metalloproteinases-4 expressed in pichia pastoris. Biol. Chem. 2001, 382, 987-991.

73. Hardy, K.M.; Booth, B.W.; Hendrix, M.J.; Salomon, D.S.; Strizzi, L. Erbb/egf signaling and emt in mammary development and breast cancer. J. Mammary Gland Biol. Neoplasia 2010, 15, 191-199.

74. Raja, W.K.; Gligorijevic, B.; Wyckoff, J.; Condeelis, J.S.; Castracane, J. A new chemotaxis device for cell migration studies. Integr. Biol. (Camb) 2010, 2, 696-706.

75. Wesche, J.; Haglund, K.; Haugsten, E.M. Fibroblast growth factors and their receptors in cancer. Biochem. J. 2011, 437, 199-213.

76. Scollen, S.; Luccarini, C.; Baynes, C.; Driver, K.; Humphreys, M.K.; Garcia-Closas, M.; Figueroa, J.; Lissowska, J.; Pharoah, P.D.; Easton, D.F.; et al. Tgf-beta signaling pathway and breast cancer susceptibility. Cancer Epidemiol. Biomark. Prev. 2011, 20, 1112-1119.

77. Swaminathan, V.; Mythreye, K.; O’Brien, E.T.; Berchuck, A.; Blobe, G.C.; Superfine, R. Mechanical stiffness grades metastatic potential in patient tumor cells and in cancer cell lines. Cancer Res. 2011, 71, 5075-5080.

78. Hanahan, D.; Weinberg, R.A. The hallmarks of cancer. Cell 2000, 100, 57-70.

79. Wendt, M.K.; Taylor, M.A.; Schiemann, B.J.; Schiemann, W.P. Down-regulation of epithelial cadherin is required to initiate metastatic outgrowth of breast cancer. Mol. Biol. Cell 2011, 22, 2423-2435.

80. Morozevich, G.; Kozlova, N.; Cheglakov, I.; Ushakova, N.; Berman, A. Integrin alpha5beta1 controls invasion of human breast carcinoma cells by direct and indirect modulation of mmp-2 collagenase activity. Cell Cycle 2009, 8, 2219-2225. 
81. Polyak, K.; Kalluri, R. The role of the microenvironment in mammary gland development and cancer. Cold Spring Harb. Perspect. Biol. 2010, 2, a003244:1-a003244:14.

82. Robinson, B.D.; Sica, G.L.; Liu, Y.F.; Rohan, T.E.; Gertler, F.B.; Condeelis, J.S.; Jones, J.G. Tumor microenvironment of metastasis in human breast carcinoma: A potential prognostic marker linked to hematogenous dissemination. Clin. Cancer Res. 2009, 15, 2433-2441.

83. Yizraeli, M.L.; Weihs, D. Time-dependent micromechanical responses of breast cancer cells and adjacent fibroblasts to electric treatment. Cell Biochem. Biophys. 2011, in press.

84. Kashani, I.; Barvarestani, M.; Etesam, F.; Shokrgozar, M.; Abdolvahabi, M.; Haddad, P.; Noori Mokohi, M.H.; Hosseinf, M. Human preadipocytes inhibit proliferation of MCF-7 breast cancer cell line. Acta Medica Iran. 2006, 44, 291-298.

85. Krause, S.; Maffini, M.V.; Soto, A.M.; Sonnenschein, C. The microenvironment determines the breast cancer cells' phenotype: Organization of mcf7 cells in $3 \mathrm{~d}$ cultures. BMC Cancer 2010, 10 , 263:1-263:13.

86. Krause, S.; Maffini, M.V.; Soto, A.M.; Sonnenschein, C. A novel 3d in vitro culture model to study stromal-epithelial interactions in the mammary gland. Tissue Eng. Part C Methods 2008, 14, 261-271.

87. Dirat, B.; Bochet, L.; Dabek, M.; Daviaud, D.; Dauvillier, S.; Majed, B.; Wang, Y.Y.; Meulle, A.; Salles, B.; Le Gonidec, S.; et al. Cancer-associated adipocytes exhibit an activated phenotype and contribute to breast cancer invasion. Cancer Res. 2011, 71, 2455-2465.

88. Poczobutt, J.M.; Tentler, J.; Lu, X.; Schedin, P.J.; Gutierrez-Hartmann, A. Benign mammary epithelial cells enhance the transformed phenotype of human breast cancer cells. BMC Cancer 2010, 10, 373:1-373:17.

89. Sasser, A.K.; Mundy, B.L.; Smith, K.M.; Studebaker, A.W.; Axel, A.E.; Haidet, A.M.; Fernandez, S.A.; Hall, B.M. Human bone marrow stromal cells enhance breast cancer cell growth rates in a cell line-dependent manner when evaluated in $3 \mathrm{~d}$ tumor environments. Cancer Lett. 2007, 254, 255-264.

90. Ingthorsson, S.; Sigurdsson, V.; Fridriksdottir, A., Jr.; Jonasson, J.G.; Kjartansson, J.; Magnusson, M.K.; Gudjonsson, T. Endothelial cells stimulate growth of normal and cancerous breast epithelial cells in 3d culture. BMC Res. Notes 2010, 3, 184:1-184:12.

91. Dimri, G.P. What has senescence got to do with cancer? Cancer Cell 2005, 7, 505-512.

92. Yaar, M.; Eller, M.S.; Panova, I.; Kubera, J.; Wee, L.H.; Cowan, K.H.; Gilchrest, B.A. Telomeric DNA induces apoptosis and senescence of human breast carcinoma cells. Breast Cancer Res. 2007, 9, R13:1-R13:13.

93. Huang, M.; Whang, P.; Lewicki, P.; Mitchell, B.S. Cyclopentenyl cytosine induces senescence in breast cancer cells through the nucleolar stress response and activation of p53. Mol. Pharmacol. 2011, 80, 40-48.

94. Callahan, R.; Hurvitz, S. Human epidermal growth factor receptor-2-positive breast cancer: Current management of early, advanced, and recurrent disease. Curr. Opin. Obstet. Gynecol. 2011, 23, 37-43.

95. Sun, J. Matrix metalloproteinases and tissue inhibitor of metalloproteinases are essential for the inflammatory response in cancer cells. J. Signal Transduct. 2010, 2010, 985132:1-985132:7. 
96. Koziczak, M.; Holbro, T.; Hynes, N.E. Blocking of fgfr signaling inhibits breast cancer cell proliferation through downregulation of d-type cyclins. Oncogene 2004, 23, 3501-3508.

97. Eckert, M.A.; Yang, J. Targeting invadopodia to block breast cancer metastasis. Oncotarget 2011, 2, 562-568.

98. Subbaram, S.; Dipersio, C.M. Integrin alpha3beta1 as a breast cancer target. Expert Opin. Ther. Targets 2011, in press.

99. Ju, J.H.; Jang, K.; Lee, K.M.; Kim, M.; Kim, J.; Yi, J.Y.; Noh, D.Y.; Shin, I. Cd24 enhances DNA damage-induced apoptosis by modulating nf- $\{$ kappa $\}$ b signaling in cd44 expressing breast cancer cells. Carcinogenesis 2011, doi: 10.1093/carcin/bgr173.

100. Joyce, J.A. Therapeutic targeting of the tumor microenvironment. Cancer Cell 2005, 7, 513-520.

101. Loh, Y.H.; Wu, Q.; Chew, J.L.; Vega, V.B.; Zhang, W.; Chen, X.; Bourque, G.; George, J.; Leong, B.; Liu, J.; et al. The oct4 and nanog transcription network regulates pluripotency in mouse embryonic stem cells. Nat. Genet. 2006, 38, 431-440.

102. Pan, G.; Thomson, J.A. Nanog and transcriptional networks in embryonic stem cell pluripotency. Cell Res. 2007, 17, 42-49.

103. Hu, J.; Qin, K.; Zhang, Y.; Gong, J.; Li, N.; Lv, D.; Xiang, R.; Tan, X. Downregulation of transcription factor oct4 induces an epithelial-to-mesenchymal transition via enhancement of $\mathrm{ca}(2+)$ influx in breast cancer cells. Biochem. Biophys. Res. Commun. 2011, 411, 786-791.

104. Guo, Y.; Graham-Evans, B.; Broxmeyer, H.E. Murine embryonic stem cells secrete cytokines/growth modulators that enhance cell survival/anti-apoptosis and stimulate colony formation of murine hematopoietic progenitor cells. Stem Cells 2006, 24, 850-856.

105. Llanes-Fernández, L.; Álvarez-Goyanes, R.I.; del Carmen Arango-, M.; Alcocer-González, J.M.; Mojarrieta, J.C.; Pérez, X.E.; López, M.O.; Odio, S.F.; Camacho-Rodríguez, R.; Guerra-Yi, M.E.; et al. Relationship between il-10 and tumor markers in breast cancer patients. Breast 2006, 15, 482-489.

106. Gerger, A.; Renner, W.; Langsenlehner, T.; Hofmann, G.; Knechtel, G.; Szkandera, J.; Samonigg, H.; Krippl, P.; Langsenlehner, U. Association of interleukin-10 gene variation with breast cancer prognosis. Breast Cancer Res. Treat. 2010, 119, 701-705.

107. Lacroix, M.; Siwek, B.; Marie, P.J.; Body, J.J. Production and regulation of interleukin-11 by breast cancer cells. Cancer Lett. 1998, 127, 29-35.

108. Hanavadi, S.; Martin, T.; Watkins, G.; Mansel, R.; Jiang, W. Expression of interleukin 11 and its receptor and their prognostic value in human breast cancer. Ann. Surg. Oncol. 2006, 13, 802-808.

109. Singer, C.F.; Kronsteiner, N.; Hudelist, G.; Marton, E.; Walter, I.; Kubista, M.; Czerwenka, K.; Schreiber, M.; Seifert, M.; Kubista, E. Interleukin 1 system and sex steroid receptor expression in human breast cancer: Interleukin lalpha protein secretion is correlated with malignant phenotype. Clin. Cancer Res. 2003, 9, 4877-4883.

110. Liu, J.; Spence, M.J.; Wallace, P.M.; Forcier, K.; Hellstrom, I.; Vestal, R.E. Oncostatin $\mathrm{m}$-specific receptor mediates inhibition of breast cancer cell growth and down-regulation of the c-myc proto-oncogene. Cell Growth Differ. 1997, 8, 667-676.

111. Liu, J.; Hadjokas, N.; Mosley, B.; Estrov, Z.; Spence, M.J.; Vestal, R.E. Oncostatin m-specific receptor expression and function in regulating cell proliferation of normal and malignant mammary epithelial cells. Cytokine 1998, 10, 295-302. 
112. Jorcyk, C.L.; Holzer, R.G.; Ryan, R.E. Oncostatin $m$ induces cell detachment and enhances the metastatic capacity of t-47d human breast carcinoma cells. Cytokine 2006, 33, 323-336.

113. Ulivi, P.; Zoli, W.; Medri, L.; Amadori, D.; Saragoni, L.; Barbanti, F.; Calistri, D.; Silvestrini, R. C-kit and scf expression in normal and tumor breast tissue. Breast Cancer Res. Treat. 2004, 83, 33-42.

114. Hines, S.J.; Litz, J.S.; Krystal, G.W. Coexpression of c-kit and stem cell factor in breast cancer results in enhanced sensitivity to members of the egf family of growth factors. Breast Cancer Res. Treat. 1999, 58, 1-10.

115. Roland, C.L.; Dineen, S.P.; Lynn, K.D.; Sullivan, L.A.; Dellinger, M.T.; Sadegh, L.; Sullivan, J.P.; Shames, D.S.; Brekken, R.A. Inhibition of vascular endothelial growth factor reduces angiogenesis and modulates immune cell infiltration of orthotopic breast cancer xenografts. Mol. Cancer Ther. 2009, 8, 1761-1771.

116. Bieche, I.; Chavey, C.; Andrieu, C.; Busson, M.; Vacher, S.; Le Corre, L.; Guinebretiere, J.M.; Burlinchon, S.; Lidereau, R.; Lazennec, G. Cxc chemokines located in the 4q21 region are up-regulated in breast cancer. Endocr. Relat. Cancer 2007, 14, 1039-1052.

117. Walser, T.C.; Rifat, S.; Ma, X.; Kundu, N.; Ward, C.; Goloubeva, O.; Johnson, M.G.; Medina, J.C.; Collins, T.L.; Fulton, A.M. Antagonism of cxcr3 inhibits lung metastasis in a murine model of metastatic breast cancer. Cancer Res. 2006, 66, 7701-7707.

118. Kim, M.Y.; Oskarsson, T.; Acharyya, S.; Nguyen, D.X.; Zhang, X.H.; Norton, L.; Massague, J. Tumor self-seeding by circulating cancer cells. Cell 2009, 139, 1315-1326.

119. Qian, B.Z.; Li, J.; Zhang, H.; Kitamura, T.; Zhang, J.; Campion, L.R.; Kaiser, E.A.; Snyder, L.A.; Pollard, J.W. Ccl2 recruits inflammatory monocytes to facilitate breast-tumour metastasis. Nature 2011, 475, 222-225.

120. Nath, A.; Chattopadhya, S.; Chattopadhyay, U.; Sharma, N.K. Macrophage inflammatory protein (mip)lalpha and miplbeta differentially regulate release of inflammatory cytokines and generation of tumoricidal monocytes in malignancy. Cancer Immunol. Immunother. 2006, 55, 1534-1541.

121. Ohara, M.; Yamaguchi, Y.; Matsuura, K.; Murakami, S.; Arihiro, K.; Okada, M. Possible involvement of regulatory $\mathrm{t}$ cells in tumor onset and progression in primary breast cancer. Cancer Immunol. Immunother. 2009, 58, 441-447.

122. Bussard, K.M.; Venzon, D.J.; Mastro, A.M. Osteoblasts are a major source of inflammatory cytokines in the tumor microenvironment of bone metastatic breast cancer. J. Cell. Biochem. 2010, 111, 1138-1148.

123. Gomes, E.M.; Rodrigues, M.S.; Phadke, A.P.; Butcher, L.D.; Starling, C.; Chen, S.; Chang, D.; Hernandez-Alcoceba, R.; Newman, J.T.; Stone, M.J.; et al. Antitumor activity of an oncolytic adenoviral-cd40 ligand (cd154) transgene construct in human breast cancer cells. Clin. Cancer Res. 2009, 15, 1317-1325.

124. Lee, S.J.; Yoo, H.J.; Bae, Y.S.; Kim, H.J.; Lee, S.T. Timp-1 inhibits apoptosis in breast carcinoma cells via a pathway involving pertussis toxin-sensitive $\mathrm{g}$ protein and c-src. Biochem. Biophys. Res. Commun. 2003, 312, 1196-1201. 
125. Michalska, A.E. Chapter 1, Unit1C.3 Isolation and propagation of mouse embryonic fibroblasts and preparation of mouse embryonic feeder layer cells. In Current Protocols in Stem Cell Biology; John Wiley and Sons, Inc.: Hoboken, NJ, USA, 2007.

126. Amit, M.; Margulets, V.; Segev, H.; Shariki, K.; Laevsky, I.; Coleman, R.; Itskovitz-Eldor, J. Human feeder layers for human embryonic stem cells. Biol. Reprod. 2003, 68, 2150-2156.

127. Lin, S.; Talbot, P. Methods for culturing mouse and human embryonic stem cells. Methods Mol. Biol. 2011, 690, 31-56.

128. Abraham, S.; Sheridan, S.D.; Miller, B.; Rao, R.R. Stable propagation of human embryonic and induced pluripotent stem cells on decellularized human substrates. Biotechnol. Prog. 2010, 26, $1126-1134$.

129. Hirai, H.; Karian, P.; Kikyo, N. Regulation of embryonic stem cell self-renewal and pluripotency by leukaemia inhibitory factor. Biochem. J. 2011, 438, 11-23.

130. Levenstein, M.E.; Ludwig, T.E.; Xu, R.H.; Llanas, R.A.; Van Den Heuvel-Kramer, K.; Manning, D.; Thomson, J.A. Basic fibroblast growth factor support of human embryonic stem cell self-renewal. Stem Cells 2006, 24, 568-574.

131. Wang, L.; Schulz, T.C.; Sherrer, E.S.; Dauphin, D.S.; Shin, S.; Nelson, A.M.; Ware, C.B.; Zhan, M.; Song, C.Z.; Chen, X.; et al. Self-renewal of human embryonic stem cells requires insulin-like growth factor-1 receptor and erbb2 receptor signaling. Blood 2007, 110, 4111-4119.

132. Gerecht, S.; Burdick, J.A.; Ferreira, L.S.; Townsend, S.A.; Langer, R.; Vunjak-Novakovic, G. Hyaluronic acid hydrogel for controlled self-renewal and differentiation of human embryonic stem cells. Proc. Natl. Acad. Sci. USA 2007, 104, 11298-11303.

133. Siti-Ismail, N.; Bishop, A.E.; Polak, J.M.; Mantalaris, A. The benefit of human embryonic stem cell encapsulation for prolonged feeder-free maintenance. Biomaterials 2008, 29, 3946-3952.

134. Wang, X.; Wang, W.; Ma, J.; Guo, X.; Yu, X.; Ma, X. Proliferation and differentiation of mouse embryonic stem cells in apa microcapsule: A model for studying the interaction between stem cells and their niche. Biotechnol. Prog. 2006, 22, 791-800.

135. Li, Z.; Leung, M.; Hopper, R.; Ellenbogen, R.; Zhang, M. Feeder-free self-renewal of human embryonic stem cells in 3d porous natural polymer scaffolds. Biomaterials 2010, 31, 404-412.

136. Raof, N.A.; Padgen, M.R.; Gracias, A.R.; Bergkvist, M.; Xie, Y. One-dimensional self-assembly of mouse embryonic stem cells using an array of hydrogel microstrands. Biomaterials 2011, 32, 4498-4505.

137. Peng, S.; Hua, J.; Cao, X.; Wang, H. Gelatin induces trophectoderm differentiation of mouse embryonic stem cells. Cell Biol. Int. 2011, 35, 587-591.

138. Farzaneh, Z.; Pournasr, B.; Ebrahimi, M.; Aghdami, N.; Baharvand, H. Enhanced functions of human embryonic stem cell-derived hepatocyte-like cells on three-dimensional nanofibrillar surfaces. Stem Cell Rev. 2010, 6, 601-610.

139. Mahairaki, V.; Lim, S.H.; Christopherson, G.T.; Xu, L.; Nasonkin, I.; Yu, C.; Mao, H.Q.; Koliatsos, V.E. Nanofiber matrices promote the neuronal differentiation of human embryonic stem cell-derived neural precursors in vitro. Tissue Eng. Part A 2011, 17, 855-863.

140. Smith, L.A.; Liu, X.; Hu, J.; Ma, P.X. The enhancement of human embryonic stem cell osteogenic differentiation with nano-fibrous scaffolding. Biomaterials 2010, 31, 5526-5535. 
141. Smith, L.A.; Liu, X.; Hu, J.; Ma, P.X. The influence of three-dimensional nanofibrous scaffolds on the osteogenic differentiation of embryonic stem cells. Biomaterials 2009, 30, 2516-2522.

142. Kang, X.; Xie, Y.; Powell, H.M.; James Lee, L.; Belury, M.A.; Lannutti, J.J.; Kniss, D.A. Adipogenesis of murine embryonic stem cells in a three-dimensional culture system using electrospun polymer scaffolds. Biomaterials 2007, 28, 450-458.

143. Xie, J.; Willerth, S.M.; Li, X.; Macewan, M.R.; Rader, A.; Sakiyama-Elbert, S.E.; Xia, Y. The differentiation of embryonic stem cells seeded on electrospun nanofibers into neural lineages. Biomaterials 2009, 30, 354-362.

144. Schiele, N.R.; Corr, D.T.; Huang, Y.; Raof, N.A.; Xie, Y.; Chrisey, D.B. Laser-based direct-write techniques for cell printing. Biofabrication 2010, 2, doi:10.1088/1758-5082/2/3/032001.

145. Postovit, L.M.; Seftor, E.A.; Seftor, R.E.; Hendrix, M.J. Influence of the microenvironment on melanoma cell fate determination and phenotype. Cancer Res. 2006, 66, 7833-7836.

146. Hendrix, M.J.; Seftor, E.A.; Seftor, R.E.; Kasemeier-Kulesa, J.; Kulesa, P.M.; Postovit, L.M. Reprogramming metastatic tumour cells with embryonic microenvironments. Nat. Rev. Cancer 2007, 7, 246-255.

147. Kasemeier-Kulesa, J.C.; Teddy, J.M.; Postovit, L.M.; Seftor, E.A.; Seftor, R.E.; Hendrix, M.J.; Kulesa, P.M. Reprogramming multipotent tumor cells with the embryonic neural crest microenvironment. Dev. Dyn. 2008, 237, 2657-2666.

148. Illmensee, K.; Mintz, B. Totipotency and normal differentiation of single teratocarcinoma cells cloned by injection into blastocysts. Proc. Natl. Acad. Sci. USA 1976, 73, 549-553.

149. Pierce, G.B.; Pantazis, C.G.; Caldwell, J.E.; Wells, R.S. Specificity of the control of tumor formation by the blastocyst. Cancer Res. 1982, 42, 1082-1087.

150. Lee, L.M.; Seftor, E.A.; Bonde, G.; Cornell, R.A.; Hendrix, M.J. The fate of human malignant melanoma cells transplanted into zebrafish embryos: Assessment of migration and cell division in the absence of tumor formation. Dev. Dyn. 2005, 233, 1560-1570.

151. Diez-Torre, A.; Andrade, R.; Eguizabal, C.; Lopez, E.; Arluzea, J.; Silio, M.; Arechaga, J. Reprogramming of melanoma cells by embryonic microenvironments. Int. J. Dev. Biol. 2009, 53, 1563-1568.

152. Ma, F.; Zhou, L.; Fang, L.Q.; Bai, J.; Zhao, J.; Wang, Y.; Wang, Z.B. Effect of mid-late mouse fetus' microenvironment on the growth of tumor cells after intrauterine transplantation. Cell Biol. Int. 2007, 31, 592-598.

153. Patton, E.E.; Widlund, H.R.; Kutok, J.L.; Kopani, K.R.; Amatruda, J.F.; Murphey, R.D.; Berghmans, S.; Mayhall, E.A.; Traver, D.; Fletcher, C.D.; et al. Braf mutations are sufficient to promote nevi formation and cooperate with p53 in the genesis of melanoma. Curr. Biol. 2005, 15, 249-254.

154. Kelleher, F.; Fennelly, D.; Rafferty, M. Common critical pathways in embryogenesis and cancer. Acta Oncol. 2006, 45, 375-388.

155. Dreesen, O.; Brivanlou, A. Signaling pathways in cancer and embryonic stem cells. Stem Cell Rev. Rep. 2007, 3, 7-17.

156. Al-Hajj, M.; Wicha, M.S.; Benito-Hernandez, A.; Morrison, S.J.; Clarke, M.F. Prospective identification of tumorigenic breast cancer cells. Proc. Natl. Acad. Sci. USA 2003, 100, 3983-3988. 
157. Marcato, P.; Dean, C.A.; Pan, D.; Araslanova, R.; Gillis, M.; Joshi, M.; Helyer, L.; Pan, L.; Leidal, A.; Gujar, S.; et al. Aldehyde dehydrogenase activity of breast cancer stem cells is primarily due to isoform aldh1a3 and its expression is predictive of metastasis. Stem Cells 2011, $29,32-45$.

158. Charafe-Jauffret, E.; Ginestier, C.; Birnbaum, D. Breast cancer stem cells: Tools and models to rely on. BMC Cancer 2009, 9, 202:1-202:10.

159. Liu, S.; Ginestier, C.; Ou, S.J.; Clouthier, S.G.; Patel, S.H.; Monville, F.; Korkaya, H.; Heath, A.; Dutcher, J.; Kleer, C.G.; et al. Breast cancer stem cells are regulated by mesenchymal stem cells through cytokine networks. Cancer Res. 2011, 71, 614-624.

160. Ginestier, C.; Charafe-Jauffret, E.; Birnbaum, D. Targeting breast cancer stem cells: Fishing season open! Breast Cancer Res. 2010, 12, 312:-312:2.

161. Liu, S.; Wicha, M.S. Targeting breast cancer stem cells. J. Clin. Oncol. 2010, 28, 4006-4012.

162. Korkaya, H.; Liu, S.; Wicha, M.S. Breast cancer stem cells, cytokine networks, and the tumor microenvironment. J. Clin. Invest. 2011, 121, 3804-3809.

163. Velasco-Velazquez, M.A.; Popov, V.M.; Lisanti, M.P.; Pestell, R.G. The role of breast cancer stem cells in metastasis and therapeutic implications. Am. J. Pathol. 2011, 179, 2-11.

164. Wong, D.J.; Liu, H.; Ridky, T.W.; Cassarino, D.; Segal, E.; Chang, H.Y. Module map of stem cell genes guides creation of epithelial cancer stem cells. Cell Stem Cell 2008, 2, 333-344.

165. Somervaille, T.C.P.; Matheny, C.J.; Spencer, G.J.; Iwasaki, M.; Rinn, J.L.; Witten, D.M.; Chang, H.Y.; Shurtleff, S.A.; Downing, J.R.; Cleary, M.L. Hierarchical maintenance of mll myeloid leukemia stem cells employs a transcriptional program shared with embryonic rather than adult stem cells. Cell Stem Cell 2009, 4, 129-140.

166. Postovit, L.M.; Seftor, E.A.; Seftor, R.E.; Hendrix, M.J. A three-dimensional model to study the epigenetic effects induced by the microenvironment of human embryonic stem cells. Stem Cells 2006, 24, 501-505.

167. Abbott, D.E.; Bailey, C.M.; Postovit, L.M.; Seftor, E.A.; Margaryan, N.; Seftor, R.E.; Hendrix, M.J. The epigenetic influence of tumor and embryonic microenvironments: How different are they? Cancer Microenviron. 2008, 1, 13-21.

168. Ben-Porath, I.; Thomson, M.W.; Carey, V.J.; Ge, R.; Bell, G.W.; Regev, A.; Weinberg, R.A. An embryonic stem cell-like gene expression signature in poorly differentiated aggressive human tumors. Nat. Genet. 2008, 40, 499-507.

169. Raof, N.A.; Raja, W.K.; Castracane, J.; Xie, Y. Bioengineering embryonic stem cell microenvironments for exploring inhibitory effects on metastatic breast cancer cells. Biomaterials 2011, 32, 4130-4139.

170. Kievit, F.M.; Florczyk, S.J.; Leung, M.C.; Veiseh, O.; Park, J.O.; Disis, M.L.; Zhang, M. Chitosan-alginate $3 \mathrm{~d}$ scaffolds as a mimic of the glioma tumor microenvironment. Biomaterials 2010, 31, 5903-5910.

171. Chen, M.C.; Gupta, M.; Cheung, K.C. Alginate-based microfluidic system for tumor spheroid formation and anticancer agent screening. Biomed. Microdevices 2010, 12, 647-654.

172. Akeda, K.; Nishimura, A.; Satonaka, H.; Shintani, K.; Kusuzaki, K.; Matsumine, A.; Kasai, Y.; Masuda, K.; Uchida, A. Three-dimensional alginate spheroid culture system of murine osteosarcoma. Oncol. Rep. 2009, 22, 997-1003. 
173. Plunkett, M.L.; Hailey, J.A. An in vivo quantitative angiogenesis model using tumor cells entrapped in alginate. Lab. Invest. 1990, 62, 510-517.

174. Yamada, K.M.; Cukierman, E. Modeling tissue morphogenesis and cancer in 3d. Cell 2007, 130, 601-610.

175. Gautier, A.; Carpentier, B.; Dufresne, M.; Vu Dinh, Q.; Paullier, P.; Legallais, C. Impact of alginate type and bead diameter on mass transfers and the metabolic activities of encapsulated c3a cells in bioartificial liver applications. Eur. Cell Mater. 2011, 21, 94-106.

176. Strand, B.L.; Morch, Y.A.; Syvertsen, K.R.; Espevik, T.; Skjak-Braek, G. Microcapsules made by enzymatically tailored alginate. J. Biomed. Mater. Res. A 2003, 64, 540-550.

177. Tan, C.S.; Jejurikar, A.; Rai, B.; Bostrom, T.; Lawrie, G.; Grondahl, L. Encapsulation of a glycosaminoglycan in hydroxyapatite/alginate capsules. J. Biomed. Mater. Res. A 2009, 91, 866-877.

178. Hannouche, D.; Terai, H.; Fuchs, J.R.; Terada, S.; Zand, S.; Nasseri, B.A.; Petite, H.; Sedel, L.; Vacanti, J.P. Engineering of implantable cartilaginous structures from bone marrow-derived mesenchymal stem cells. Tissue Eng. 2007, 13, 87-99.

179. Wang, N.; Adams, G.; Buttery, L.; Falcone, F.H.; Stolnik, S. Alginate encapsulation technology supports embryonic stem cells differentiation into insulin-producing cells. J. Biotechnol. 2009, 144, 304-312.

180. Hwang, Y.S.; Cho, J.; Tay, F.; Heng, J.Y.; Ho, R.; Kazarian, S.G.; Williams, D.R.; Boccaccini, A.R.; Polak, J.M.; Mantalaris, A. The use of murine embryonic stem cells, alginate encapsulation, and rotary microgravity bioreactor in bone tissue engineering. Biomaterials 2009, 30, 499-507.

181. Maguire, T.; Davidovich, A.E.; Wallenstein, E.J.; Novik, E.; Sharma, N.; Pedersen, H.; Androulakis, I.P.; Schloss, R.; Yarmush, M. Control of hepatic differentiation via cellular aggregation in an alginate microenvironment. Biotechnol. Bioeng. 2007, 98, 631-644.

182. Zhao, L.; Tang, M.; Weir, M.D.; Detamore, M.S.; Xu, H.H. Osteogenic media and rhbmp-2-induced differentiation of umbilical cord mesenchymal stem cells encapsulated in alginate microbeads and integrated in an injectable calcium phosphate-chitosan fibrous scaffold. Tissue Eng. Part A 2011, 17, 969-979.

183. Bai, H.Y.; Chen, G.A.; Mao, G.H.; Song, T.R.; Wang, Y.X. Three step derivation of cartilage like tissue from human embryonic stem cells by $2 \mathrm{~d}-3 \mathrm{~d}$ sequential culture in vitro and further implantation in vivo on alginate/plga scaffolds. J. Biomed. Mater. Res. A 2010, 94, 539-546.

184. Trivedi, N.; Keegan, M.; Steil, G.M.; Hollister-Lock, J.; Hasenkamp, W.M.; Colton, C.K.; Bonner-Weir, S.; Weir, G.C. Islets in alginate macrobeads reverse diabetes despite minimal acute insulin secretory responses. Transplantation 2001, 71, 203-211.

185. Dufrane, D.; Goebbels, R.M.; Gianello, P. Alginate macroencapsulation of pig islets allows correction of streptozotocin-induced diabetes in primates up to 6 months without immunosuppression. Transplantation 2010, 90, 1054-1062.

186. Dufrane, D.; Goebbels, R.M.; Saliez, A.; Guiot, Y.; Gianello, P. Six-month survival of microencapsulated pig islets and alginate biocompatibility in primates: Proof of concept. Transplantation 2006, 81, 1345-1353. 
187. Fritschy, W.M.; Wolters, G.H.; van Schilfgaarde, R. Effect of alginate-polylysine-alginate microencapsulation on in vitro insulin release from rat pancreatic islets. Diabetes 1991, 40, 37-43.

188. Xu, M.; Wang, X.; Yan, Y.; Yao, R.; Ge, Y. An cell-assembly derived physiological 3d model of the metabolic syndrome, based on adipose-derived stromal cells and a gelatin/alginate/fibrinogen matrix. Biomaterials 2010, 31, 3868-3877.

189. Ruvinov, E.; Leor, J.; Cohen, S. The promotion of myocardial repair by the sequential delivery of igf-1 and hgf from an injectable alginate biomaterial in a model of acute myocardial infarction. Biomaterials 2011, 32, 565-578.

(C) 2011 by the authors; licensee MDPI, Basel, Switzerland. This article is an open access article distributed under the terms and conditions of the Creative Commons Attribution license (http://creativecommons.org/licenses/by/3.0/). 